\title{
Environmental variability off NE Greenland (western Fram Strait) during the past 10,000 years
}

Marc Zehnich ${ }^{1,2}$, Robert F. Spielhagen², Henning A. Bauch ${ }^{2,3}$, Matthias Forwick ${ }^{4}$, H. Christian Hass ${ }^{3}$, Tina Palme ${ }^{2}$, Ruediger Stein ${ }^{3,5}$, Nicole Syring ${ }^{3}$

${ }^{1}$ Academy of Sciences, Humanities and Literature, Mainz, Germany

${ }^{2}$ GEOMAR Helmholtz Centre for Ocean Research, Kiel, Germany

${ }^{3}$ Alfred Wegener Institute for Polar and Marine Research, Bremerhaven, Germany

${ }^{4}$ Department of Geosciences UiT The Arctic University of Norway, Tromsø, Norway

${ }^{5}$ MARUM and Faculty of Geosciences, University of Bremen, Bremen, Germany

\begin{abstract}
To reconstruct the climatic and paleoceanographic variability offshore Northeast Greenland during the last $\sim 10$ ka with multidecadal resolution, sediment core PS93/025 from the outermost North-East Greenland continental shelf $\left(80.5^{\circ} \mathrm{N}\right)$ was studied by a variety of micropaleontological, sedimentological and isotopic methods.

High foraminiferal fluxes, together with high proportions of ice-rafted debris and high $\mathrm{Ca} / \mathrm{Fe}$ ratios, indicate a maximum in bioproductivity until $\sim 8$ ka related to a low sea-ice coverage. Sortable silt values, planktic foraminifer associations, and stable isotope data of planktic and benthic foraminifers suggest a strong westward advection of relatively warm Atlantic Water by the Return Atlantic Current during this time, with a noticeable bottom current activity. This advection may have been facilitated by a greater water depth at our site, resulting from postglacial isostatic depression. For the following midHolocene interval (ca. 8-5 ka), isotope data, lower foraminiferal fluxes and a shift in grain size maxima point to a lasting but successively decreasing Atlantic Water inflow, a weakening productivity, and a growing sea-ice coverage which is also revealed by the $\mathrm{P}_{\mathrm{III}} \mathrm{IP}_{25}$ index.

A final stage in the environmental development was reached at $\sim 5$ ka with the establishment of preindustrial conditions. Low $\mathrm{Ca} / \mathrm{Fe}$ ratios, low foraminiferal fluxes, low sortable silt values and the sea-ice indicating $\mathrm{P}_{\mathrm{III}} \mathrm{I}_{25}$ index point to a limited productivity and a weak Atlantic Water inflow by the Return Atlantic Current to our research area, as well as a higher and/or seasonally more extended sea-ice coverage during the Late Holocene. Two intervals with somewhat enhanced Atlantic Water advection around 2.0 and $1.0 \mathrm{ka}$ are indicated by slightly increased foraminiferal fluxes and the reoccurrence of subpolar foraminifers. These intervals may correlate with the Roman Warm Period and the Medieval Climate Anomaly, as defined in the North Atlantic region.
\end{abstract}

Keywords: Fram Strait, Greenland, Holocene, Sea-ice, Atlantic Water, Foraminifers, Stable isotopes, Ice-rafted debris, Water masses, Paleoceanography 


\section{Introduction}

The Fram Strait and especially the Greenland Sea play a major role in the modern global oceanclimate system since the latter is one of only few areas where convection and deep water formation takes place, contributing to the renewal of the North Atlantic Deep Water (NADW) (Rudels and Quadfasel, 1991). This water mass is part of the deep Atlantic Meridional Overturning Circulation (AMOC) which exerts a strong control on the stratification and distribution of water masses, the ocean heat transport (e.g., northward advection of relatively warm Atlantic Water) and the cycling and storage of substances like carbon dioxide (Kuhlbrodt et al., 2007). Regarding the deep convection, the contrast between poleward flowing warm and saline surface waters and cold, perennially or seasonally ice-covered, polar low-saline surface waters is important as it allows, through mixing, the formation of dense near-surface water masses which sink to depth once a certain density is reached (Hansen and Østerhus, 2000; Marshall and Schott, 1999). Subsequently, the newly formed deep water leaves the Nordic Seas (Barents Sea, Greenland Sea, Iceland Sea, Norwegian Sea) as the Denmark Strait overflow and the Iceland-Scotland overflow, spreading into all major ocean basins (Hansen and Østerhus, 2000). A second source of dense water is the sea-ice production and brine accumulation in the Arctic Ocean, leading to highly saline shelf bottom waters, which eventually cross the shelf break and sink into the deep basins (Rudels et al., 2005).

The cold, low-saline water which derives from the Arctic Ocean is fed by the enormous freshwater discharges of Siberian and North American rivers and reaches the Greenland Sea through the Fram Strait between Greenland and Svalbard (Swift, 1986). Ocean circulation and climate model experiments revealed that an excessive amount of freshwater input can affect the AMOC, since it can weaken the deep convection or even lead to its complete collapse (Condron and Winsor, 2012; Otterå et al., 2003; Rahmstorf, 2002). Recent studies of the Zachariæ Isstrøm (ZI) (Mouginot et al., 2015) and the Nioghalvfjerdsfjorden Glacier (NG) (Mayer et al., 2018) (Fig. 1a) document a massive retreat and thinning of these major glaciers in Northeast Greenland due to increased melting, likely related to higher air and ocean temperatures. Between 1998 and 2016, the NG has lost almost one third of its thickness. Numerical simulations reveal ongoing thinning, leading to large areas of unstable thin ice and the widespread disappearance of the ice shelf within the next decades (Mayer et al., 2018). Since the ocean seems to be the main driver behind these drastic changes (Mayer et al., 2018), variations of near-surface water masses in the Fram Strait, which connects the cold Arctic Ocean with the northern North Atlantic and its warm and saline waters, are of major importance. During the last decades several warm events in the Arctic and the Fram Strait went along with significant increases of Atlantic Water (AW) advection or temperature increases of the advected AW (e.g., Beszczynska-Möller et al., 2012; Karcher et al., 2003; Polyakov et al., 2017). Periods of comparable heat advection by AW in the Early and mid-Holocene are recorded in sedimentary sequences on the western Svalbard margin and were investigated on subcentennial-scale temporal resolution (e.g., Aagaard-Sørensen et al., 2014; Müller et al., 2012; Werner et al., 2013, 2016). However, until recently only very few Holocene environmental records existed from the western Fram Strait (Bauch et al., 2001a; Nørgaard-Pedersen et al., 2003), all of them having only a millennial-scale resolution. To improve our knowledge of Holocene environmental changes in this area, we present a set of new, high-resolution proxy records 
from a core obtained on the outer NE Greenland shelf. This allows us, for the first time, to reconstruct the Holocene variability of freshwater export from the Arctic, the westward advection of AW and the parameters of near-surface water mass $(0-300 \mathrm{~m})$ on time scales which are comparable to modern changes in the area.

\section{Study area}

The area between Greenland and Svalbard is characterized by two major current systems, namely the West Spitsbergen Current (WSC) which enters the Arctic Ocean through the eastern Fram Strait, and the East Greenland Current (EGC) which leaves the Arctic Ocean along the Greenland margin towards the Greenland Sea (Fig. 1a). The inflowing Atlantic Water of the WSC originates from the Norwegian Atlantic Current (NwAC) in the south, where a part branches off into the Barents Sea and another part follows the slope northwards. Around Svalbard it encounters the colder, less saline Arctic Surface Water, sinks down in the water column and flows as a subsurface current into the Arctic Ocean. Due to its counterclockwise movement in the Arctic Ocean, it later returns to the Fram Strait (Johannessen, 1986). The outflowing Polar Water, which is formed in the Arctic Ocean and enters the Greenland Sea via the EGC, is cold and fresh $\left(T<0^{\circ} \mathrm{C}\right.$ and $\left.\mathrm{S}<34.4\right)$ whereas the Atlantic Water is warm and saline ( $T$ of about 6 to $10^{\circ} \mathrm{C}$ and $S$ between 35.1 and 35.3 in summer) (Swift, 1986). In consequence, the western Fram Strait is perennially sea-ice covered whereas the eastern Fram Strait is perennially to seasonally ice-free. Compared to the stable EGC, the WSC is much more variable. Due to the complicated topographic structure of the eastern Fram Strait, it splits into at least three branches, of which one flows around Svalbard (Svalbard Branch, SB), one along the Yermak Plateau (Yermak Branch, YB) and one recirculates in the Fram Strait (Return Atlantic Current, RAC) (Fig. 1a) (Gascard et al., 1995; Johannessen et al., 1987; Quadfasel et al., 1987). The latter is linked to eddies generated by instabilities in the current which preferentially follow topographic features like the Hovgaard Fracture Zone, the Molloy Fracture Zone or the Spitsbergen Fracture Zone. Through this RAC, warm and salty Atlantic waters are transported westward across the strait (Gascard et al., 1995). Several studies imply that the recirculation may extend as far as or beyond $81^{\circ} \mathrm{N}$ (Gascard et al., 1995; Kawasaki and Hasumi, 2016; Marnela et al., 2013; Richter et al., 2018; Schlichtholz and Houssais, 1999). Until recently the SB was supposed to be the main flow of AW into the Arctic (Manley, 1995). However, Koenig et al. (2017) suggested that the Yermak Pass Branch (YPB) located between the YB and $S B$ is responsible for the main volume transport of AW to the Arctic Ocean.

[insert Fig. 1]

Fig. 1: a) Overview map of the study area displaying the locations of the investigated sediment record PS93/025 (gray dot) and the other sediment cores (yellow dots) mentioned in the text. Warm and saline Atlantic Water and cold, polar waters of Arctic origin are indicated by red and blue arrows, respectively. $\mathrm{KCL}=$ Kronprins Christian Land, $\mathrm{NG}=$ Nioghalvfjerdsfjorden Glacier, $\mathrm{SB}=$ Svalbard Branch, YB = Yermak Branch, YP = Yermak Plateau, ZI = Zachariæ Isstrøm. b) Generalized vertical structure of the Fram Strait water column at $79^{\circ} \mathrm{N}$ (modified from Laukert et al., 2017). AW = Atlantic 
Water; AIW = Arctic Intermediate Water; CBDW = Canada Basin Deep Water; dAAW = dense Arctic Atlantic Deep Water; EBDW/GSDW = Eurasian Basin Deep Water/Greenland Sea Deep Water; NDW $=$ Nordic Seas Deep Water; RAW $=$ Return Atlantic Water. c) Water column at $80.3^{\circ} \mathrm{N}$ on the NE Greenland shelf (modified from Richter et al., 2018). AAW = Arctic Atlantic Water; DW = Deep Water; PSW $=$ Polar Surface Water.

In the western Fram Strait $\left(79^{\circ} \mathrm{N}\right)$ the upper water column $(\sim 300 \mathrm{~m})$ consists of Polar and Shelf waters. Below, patches of Return Atlantic Water (RAW), warm and saline water masses transported by the RAC across the strait, are found. At greater depths of $\sim 400$ to $\sim 900 \mathrm{~m}$, dense Arctic Atlantic Water (dAAW) is located. Arctic Intermediate Water (AIW) prevails underneath the RAW/dAAW in the western and under the AW in the eastern Fram Strait. While the underlying Upper Polar Deep Water (UPDW) is restricted to the continental slope of Greenland, Nordic Seas Deep Water (NDW) is confined to the Svalbard continental slope. Canada Basin Deep Water (CBDW) and Eurasian Basin Deep Water (EBDW) or Greenland Sea Deep Water (GSDW) can be found in the deeper parts of the strait on both sides (Fig. 1b) (Laukert et al., 2017). Our sediment site, cored at ca. $290 \mathrm{~m}$ water depth in the easternmost part of the Westwind Trough $\left(80.5^{\circ} \mathrm{N}\right)$, is located within Arctic Atlantic Water (AAW) above the Deep Water (DW) and underneath the Polar Surface Water (PSW) (Fig. 1c) (Richter et al., 2018). All discussed sediment records were obtained from sites within Atlantic-derived water masses (Fig. 1b, c).

\section{Material and methods}

The $264 \mathrm{~cm}$ long sediment record from site PS93/025, consisting of the Giant box core (GKG) PS93/025-1 (80.481 ${ }^{\circ} \mathrm{N}, 8.487^{\circ} \mathrm{W}, 291.3 \mathrm{~m}$ water depth) and the Kastenlot core (KAL) PS93/025-2 $\left(80.482^{\circ} \mathrm{N}, 8.490^{\circ} \mathrm{W}, 290.2 \mathrm{~m}\right.$ water depth), was obtained during the expedition PS93.1 (2015) (Stein, 2016) of RV Polarstern on the outermost NE Greenland shelf in the western Fram Strait (Fig. 1a). To record the Holocene environmental history at the highest possible temporal resolution, the site was carefully selected by using the shipboard parametric sediment echosounder system PARASOUND. Cores from the investigated sediment record were retrieved from a several kilometers wide sedimentfilled morphological depression. The recovered sedimentary sequence mainly consists of dark grayish brown homogenous silty clay (Fig. 2c). Both cores were correlated visually and by using the existing overlap of coarse fraction content values. No apparent offset could be noticed and therefore records were combined at $20 \mathrm{~cm}$ (Fig. 2c). In the following, the composite record is referred to as "core PS93/025".

[insert Fig. 2]

Fig. 2: a) Age-depth model (polynomial fit: $33.227 * x+0.026606 * x^{2}$ ) of core $P S 93 / 025$, displayed as a blue line. Single dates are displayed as circles, given with vertical bars indicating the uncertainty ranges. Dates marked by red circles were excluded for reasons discussed in chapter 4 . Dry bulk density data are shown as a gray line, together with the linear regression $(0.77786+0.0011101 * x)$ 
used for the calculation of flux rates. b) Calculated sedimentation and accumulation rates, indicated by yellow and red lines, respectively. The dashed yellow line displays the sedimentation rates based on the calculation between the individual radiocarbon-dated levels. Sedimentation rates of PS93/025 according to the Bchron age model presented in Syring et al. (2020) are shown in the insert. c) Composite image of record PS93/025, consisting of GKG PS93/025-1 and KAL PS93/025-2.

Sediment sampling was carried out in $0.5 \mathrm{~cm}$ intervals between 0 and $10 \mathrm{~cm}$ core depth and in $1 \mathrm{~cm}$ intervals between 10 and $264 \mathrm{~cm}$ core depth. The samples were freeze-dried, wet-sieved with deionized water through a $63 \mu \mathrm{m}$-sized mesh to remove clay and silt material, and split into predefined size fractions using $125,250,500$ and $1,000 \mu \mathrm{m}$ sieves where every fraction was weighed. Dry bulk density (DBD) was determined from freeze-dried $20 \mathrm{~cm}^{3}$ samples (20 ml syringes) at $5 \mathrm{~cm}$ intervals in the uppermost $20 \mathrm{~cm}$ and at $10 \mathrm{~cm}$ intervals down to $260 \mathrm{~cm}$. To account for some randomly occurring volume variations resulting from the sampling process, a linear regression was used to calculate DBD values for individual core depths.

For the determination of foraminiferal contents, the samples were dry-sieved again to obtain the 100$250 \mu \mathrm{m}$ size fraction. In representative splits (at least $>100$ specimens; if available $>300$ specimens) of this size fraction, planktic and benthic foraminifers were determined and counted. Between 0 and 121 $\mathrm{cm}$ core depth $<100$ planktic foraminifers and between 1 and $9.5 \mathrm{~cm}$ core depth $<100$ benthic foraminifers were present in each sample. Those samples were still used to obtain a complete record. Benthic and planktic foraminiferal fluxes (individuals $/ \mathrm{cm}^{2} * \mathrm{ka}$ ) were calculated to serve as a semiquantitative proxy for bioproductivity. Fragmentation of planktic foraminifers was calculated by counting fragments which were no more determinable to species level. Thereby, the equation from Pfuhl and Shackleton (2004) was used which includes a fragment-divisor of 3. The percentage share of the subpolar planktic foraminifer species Turborotalita quinqueloba and the polar planktic species Neogloboquadrina pachyderma (morphologically left coiling) was calculated as a proxy for the advection of warmer water masses (e.g., Volkmann, 2000).

For stable oxygen and carbon isotope analyses, ca. 30 specimens of $N$. pachyderma and the benthic foraminifer species Cassidulina neoteretis from the 100-250 $\mu \mathrm{m}$ fraction were used. The measurement interval is $1 \mathrm{~cm}$ for both species between 264 and $93 \mathrm{~cm}$, whereas it shifts to ca. $2 \mathrm{~cm}$ for the benthic species and $5 \mathrm{~cm}$ for the planktic species between $93 \mathrm{~cm}$ and $0.5 \mathrm{~cm}$, due to low numbers of specimens. All analyses were carried out on a MAT 253 mass spectrometer system and a KIEL IV Carbonate Preparation Device at the GEOMAR Stable Isotope Laboratory with a long-term analytical accuracy of $<0.06 \%$ for $\delta^{18} \mathrm{O}$ and $<0.03 \%$ for $\delta^{13} \mathrm{C}$. Results are expressed in the $\delta$ notation referring to the PDB (Pee Dee Belemnite) standard while using NBS 19. Since the $\delta^{18} \mathrm{O}$ values of the two analyzed species differ from their isotopic calcite equilibrium, they were corrected for their vital effects (C. neoteretis $+0.02 \%$ and N. pachyderma $+1.02 \%$ ) (cf. Poole et al., 1994; Volkmann and Mensch, 2001).

Ice-rafted debris counts were performed on the $>150 \mu \mathrm{m}$ fraction at steps of $5 \mathrm{~cm}$. The results are expressed as flux rates (grains $/ \mathrm{cm}^{2} * \mathrm{ka}$ ). Additionally, the corresponding petrographic grain composition was analyzed to determine the source area(s) of these lithic particles by using the following groups: a) clastic sedimentary rocks (e.g., siltstones); b) metamorphic rocks (e.g., 
quartzites), volcanic rocks (e.g., basalt), olivine grains, volcanic glass shards, mica; c) crystalline rocks, quartz and feldspar; d) limestones and dolomites. Rounded grains were specified following St John et al. (2015) to identify the influence of sea-ice sediments. In this study, grains with subrounded and rounded shape were counted and grouped as "rounded".

To further determine the geochemical characteristics of the obtained sediment record, an Avaatech XRF core scanner was used at UiT The Arctic University of Norway with a down-core resolution of 1 $\mathrm{cm}$. Down-core profiles were created using the element ratio $\mathrm{Ca} / \mathrm{Fe}$ as a proxy for paleoproductivity and $\mathrm{Ti} / \mathrm{Al}$ and $\mathrm{Ti} / \mathrm{K}$ as indicators for possible changes in terrigenous sediment provenance (cf. Croudace et al., 2006; Richter et al., 2006; Spofforth et al., 2008; Vare et al., 2009). Ti is a common constituent of rocks and primarily indicates a terrigenous continental source. It is not affected by diagenetic overprinting or biological processes (Rothwell and Croudace, 2015). Accordingly, a stable Ti signal throughout a sediment core reflects a stable continental source region during the time of deposition.

To estimate the variability of paleocurrents, the sortable silt fraction was analyzed at the AWI Wadden Sea Station Sylt using a Cilas 1180 particle size analyzer, which measures the grain size distribution for each sample in a range between 0.04 and $2,500 \mu \mathrm{m}$. Prior to analysis the samples were chemically treated according to Hass et al. (2010). Sediments between 10 and $63 \mu \mathrm{m}$ (sortable silt fraction), which are assumed to be physically sortable by the currents, were used to investigate the current strength. To overcome the problem of changing sediment supply over time, sortable silt mean grain sizes were calculated (cf. McCave et al., 1995). Potentially existing influences of ice-rafted debris were reduced using the method of Hass (2002). This method allows to detect contributions of IRD to the silt fraction and provides a calculation of sortable silt values which are assumed to truly reflect current speed variations. Since the particle size analyzer measures the entire spectrum of grain sizes and their frequency in one sample, the resulting grain size distribution curves can also be used to differentiate between different types of sediment transport (cf. Clark and Hanson, 1983).

\section{Age control and sedimentation rates}

The core chronology is based on 14 accelerator mass spectrometry (AMS) radiocarbon dates obtained from benthic and planktic foraminifers as well as bivalves, scaphopods and their fragments (Table 1). Ages from the Leibniz Laboratory of Kiel University (KIA) and BETA Analytic (BETA) were measured as a graphite target on relatively large samples (ca. $1 \mathrm{mg} \mathrm{C}$ ), whereas ages from the AWI MICADAS Laboratory Bremerhaven (AWI) were measured as a gas target on rather small samples (ca. $90 \mu \mathrm{g} \mathrm{C)}$. Radiocarbon age KIA 51161 (bivalve) is excluded because of consistent measurements on benthic foraminifers in this depth range. KIA 52141 (bivalve) originates from the core catcher (CC) with no exact depth indication. Sediment disturbance cannot be excluded here and the slightly older age from $260 \mathrm{~cm}$ appears more reliable. Three datings (KIA 52139, BETA 445522, KIA 51162) gave results with a significant offset from the general age-depth trend. Since these ages result from scaphopods and bivalves, both known for their burrowing behavior, the related younger ${ }^{14} \mathrm{C}$ values may result from dated organisms which lived inside the sediment while feeding on fresh material from near the sediment-water interface or the upper, ventilated sediment layer. Radiocarbon ages were 
converted to calendar years BP (before present, present $=1950$ ) by applying the calibration software Calib 7.1 (Stuiver and Reimer, 1993) with the Marine13 calibration curve (Reimer et al., 2013), which includes a time-dependent global ocean reservoir correction of about 400 years. The oldest measured age is about 10,213 calendar years BP (a), i.e., 10.2 calendar kiloyears BP (ka), at $260 \mathrm{~cm}$. Chronology is established on the basis of a second-order polynomial fit $\left(R^{2}=0.99\right)$ (Fig. 2a). According to this formula, the age of the core base is $10.6 \mathrm{ka}$.

Uniform appearance and composition of the sediments, as well as the consistent texture seen in the studied X-ray radiographs (available at www.pangaea.de), do not hold any evidence for abrupt changes in the record. However, a calculation of linear sedimentation rates between radiocarbondated levels reveals two plateaus with apparently unusually high rates (around $100 \mathrm{~cm} / \mathrm{ka}$ ) between 42.5 and $62.5 \mathrm{~cm}$ and between 125.5 and $141.5 \mathrm{~cm}$ (Fig. 2b). Such abrupt changes (if they existed) could only result from equally abrupt quantitative changes in the deposition of the main sediment components. None of the proxy records presented here (e.g., foraminiferal contents, grain size, icerafted debris, organic carbon content) display significant changes that would corroborate such erratic jumps in sedimentation. It can be assumed that these exceptionally high rates are artefacts caused by the random distribution of datable material. Using the mentioned second-order polynomial fit and the corresponding ages results in sedimentation rates ranging between 22 and $31 \mathrm{~cm} / \mathrm{ka}$. To account for sediment compaction, accumulation rates were calculated. These range between 23.1 and 24.1 $\mathrm{g} / \mathrm{cm}^{2} * \mathrm{ka}$.

Syring et al. (2020) present an alternative age model based on the use of the Bayesian R package Bchron (Parnell et al., 2008) which, in principle, may better reflect the variable nature of sediment input or flux under changing climatic conditions, since the second-order polynomial fit can only curve once. However, the Bchron method takes datings at face value and does not account for possible displacements of the dated organism remains by, e.g., bioturbation, active burrowing or current transport. Considering the additional information regarding the often rather smooth (and not abrupt) changes in basic sediment parameters, it seems sufficiently justified to use the alternative polynombased age model that suggests no rapid jumps in sedimentation and accumulation rates. After all, the general trends of paleoenvironmental changes are very similar for both models and temporal differences are $<1,000$ years.

[insert Table 1]

Table 1: AMS radiocarbon measurements and calibrated ages (median probability) of sediment record PS93/025. For calibration the software Calib 7.1 (Stuiver and Reimer, 1993) and the Marine13 calibration curve (Reimer et al., 2013), which includes a time-dependent global ocean reservoir correction of about 400 years, were used. Red datings are excluded and correspond to the red circles in Fig. 2a. Radiocarbon age AWI 2053.1.1 (15.5 cm) was measured on material from GKG PS93/0251. 


\section{Results}

\subsection{Foraminifer occurrences}

Planktic (up to 2,350 individuals $/ \mathrm{cm}^{2} * \mathrm{ka}$ ) and benthic (up to 15,000 individuals $/ \mathrm{cm}^{2} * \mathrm{ka}$ ) foraminiferal fluxes were high between 10.6 and 8.0 ka and decreased rapidly thereafter (Fig. 3c, d). Beginning at $4.4 \mathrm{ka}$, the flux rates tended to zero. Around $2.2 \mathrm{ka}$ and between 1.2 and $0.3 \mathrm{ka}$, benthic foraminiferal fluxes were slightly higher than before (Fig. 3c). Highest planktic foraminiferal fragmentation occurred between 10.6 and $8.0 \mathrm{ka}(\sim 30 \%)$, followed by a decrease until approximately $5.0 \mathrm{ka}$. Thereafter, the values were low but highly variable (0-20\%) (Fig. 3b).

$N$. pachyderma percentages are high throughout the record $(>80 \%)$, whereas T. quinqueloba percentages are rather low (around 5-10\%). Right coiling Neogloboquadrina incompta (Darling et al., 2006), formerly N. pachyderma (dex.), Globigerina inflata and Globigerinita glutinata are rarely found. A more or less continuous appearance of $T$. quinqueloba is noted between 10.6 and $5.6 \mathrm{ka}$, whereas the following interval between 4.6 and 2.4 ka was characterized by the absence of this species. Afterwards, T. quinqueloba was present in two short intervals only, from 2.4 to 2.0 ka and from 1.6 to $1.0 \mathrm{ka}$ (Fig. 3e).

[insert Fig. 3]

Fig. 3: a) June insolation at $80^{\circ} \mathrm{N}$ (Laskar et al., 2004). b) Planktic foraminiferal fragmentation. c) Benthic foraminiferal flux rates. MCA = Medieval Climate Anomaly; RWP = Roman Warm Period. d) Planktic foraminiferal flux rates. Comparable values of core PS1230-1 (Bauch et al., 2001a) are displayed as a blue line. The $\mathrm{P}_{\mathrm{III}} \mathrm{P}_{25}$ index of our core (Syring et al., 2020) is shown in purple. e) Planktic foraminiferal percentages of $N$. pachyderma (black) and T. quinqueloba (red). Circles mark depths/ages with no planktic foraminifers. The interval with very low numbers of foraminifers is marked. Proportions of $T$. quinqueloba in core PS1230-1 (Bauch et al., 2001a) are shown as a blue line.

\subsection{Stable isotopes}

The $\delta^{13} \mathrm{C}$ isotope values of $N$. pachyderma reveal an overall positive trend from the core base until $\sim 3$ ka. From 10.6 to $8.1 \mathrm{ka}, \delta^{13} \mathrm{C}$ values are relatively stable and low $(\sim 0.3 \%)$ with two pronounced minima at 10.0 and $8.15 \mathrm{ka}$. Afterwards, $\delta^{13} \mathrm{C}$ values increase gradually until $6.85 \mathrm{ka}$. This trend is followed by a plateau of high and stable values until around $3.0 \mathrm{ka}$. The last $200 \mathrm{a}$ are marked by low $\delta^{13} \mathrm{C}$ values near $0.35 \%$ (Fig. 4a). Planktic $\delta^{18} \mathrm{O}$ values of $N$. pachyderma vary around $4.2 \%$ between 10.6 and $7.8 \mathrm{ka}$. Thereafter follows a plateau with values of high variability near $4.0 \%$ until $\sim 4.1 \mathrm{ka}$. At 4.1-1.4 ka, values are highly variable. Highest $\delta^{18} \mathrm{O}$ values are reached around 1.6 and $0.7 \mathrm{ka}$ $(\sim 5.0 \%$ ). Lower values near $3.25 \%$ characterize the last 200 a (Fig. 4b).

Benthic $\delta^{13} \mathrm{C}$ values of $C$. neoteretis rise with some internal variability until $\sim 4.3 \mathrm{ka}$. Afterwards, values

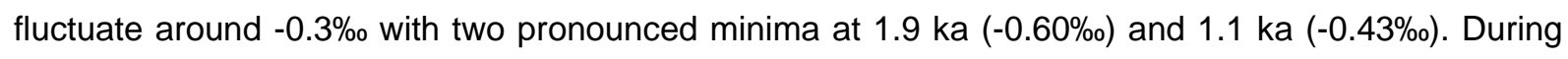
the last $\sim 400 \mathrm{a}$, values decrease to $-0.79 \%$ (Fig. $4 \mathrm{c}$ ). Benthic $\delta^{18} \mathrm{O}$ values display an overall trend to higher values until $\sim 1.5 \mathrm{ka}$. Between 10.6 and $8.2 \mathrm{ka}, \delta^{18} \mathrm{O}$ values are low with minor internal 
variability. This is followed by an increase reaching values near $5.5 \%$ around $1.5 \mathrm{ka}$. After $1.4 \mathrm{ka}$, decreasing values until present can be observed (Fig. 4d). The $\delta^{18} \mathrm{O}$ difference between $N$. pachyderma and $C$. neoteretis is low $(\sim 0.1 \%)$ between 10.6 and $7.3 \mathrm{ka}$ and comparatively high $(\sim 0.5 \%$ o) thereafter (Fig. 4 e).

[insert Fig. 4]

Fig. 4: a) Stable planktic ( $N$. pachyderma) $\delta^{13} \mathrm{C}$ values. b) Stable planktic $\delta^{18} \mathrm{O}$ values. c) Stable benthic (C. neoteretis) $\delta^{13} \mathrm{C}$ values. d) Stable benthic $\delta^{18} \mathrm{O}$ values. The 3-point moving average of our isotope records is shown in red. Isotope records of comparable sites are displayed by orange (3-point moving average) (MSM5/5-712-2; Werner et al., 2013) and blue (PS1230-1; Bauch et al., 2001a) lines. Red bars indicate warm intervals deriving from outstanding isotope peaks. MCA $=$ Medieval Climate Anomaly; RWP $=$ Roman Warm Period. e) $\delta^{18} \mathrm{O}$ difference between $N$. pachyderma and $C$. neoteretis. Dashed red lines mark averages over the indicated time intervals.

\subsection{Sediment composition}

The number of lithic particles in the size fraction 150-250 $\mu \mathrm{m}$ reveals a negative, almost linear trend throughout the entire record, whereby the flux rates decrease from 6,900 to $400 \mathrm{grains} / \mathrm{cm}^{2} * \mathrm{ka}$ (Fig. $5 \mathrm{a})$. Highest values can be found between 10.6 and $8.3 \mathrm{ka}$. Beginning at $4.0 \mathrm{ka}$, values remain below 3,000 grains $/ \mathrm{cm}^{2} * \mathrm{ka}$. Within the last $2.1 \mathrm{ka}$, the flux rates are almost constant with approximately 800 grains $/ \mathrm{cm}^{2} * \mathrm{ka}$. Around $4.4 \mathrm{ka}$, values show a temporary high, reaching over $10,200 \mathrm{grains} / \mathrm{cm}^{2} * \mathrm{ka}$ (Fig. 5a). The proportion of rounded grains varies around 45\% between 10.6 and $8.6 \mathrm{ka}$ and $40 \%$ between 8.4 and $5.2 \mathrm{ka}$. Afterwards the percentage share steadily increases, reaching highest values around $55 \%$ beginning at $2.9 \mathrm{ka}$ (Fig. 5a). The composition of ice-rafted debris shows only minor variability and is dominated by crystalline rocks, quartz and feldspar ( $65 \%)$. Metamorphic rocks (e.g., quartzites), volcanic rocks (e.g., basalt), olivine grains, volcanic glass shards and mica (muscovite, biotite) vary around $32.5 \%$ while clastic sedimentary rocks $(\sim 2 \%)$ and carbonates $(<0.5 \%)$ are rare (Fig. 5b).

[insert Fig. 5]

Fig. 5: Composition of bulk sediment and ice-rafted debris in core PS93/025. a) Upper panel: Proportions of rounded grains (black) and percentages of crystalline rocks, quartz (main component) and feldspar (pink); lower panel: Flux rates of ice-rafted debris in PS93/025 (150-250 $\mu \mathrm{m})$ and PS1230-1 (Bauch et al., 2001a) (150-500 $\mu \mathrm{m})$. b) Composition of ice-rafted debris versus depth and age, given as percentages of: Clastic sedimentary rocks (light gray), metamorphic rocks, volcanic rocks, olivine grains, volcanic glass shards and mica (black), crystalline rocks, quartz and feldspar (pink), limestones and dolomites (orange; values are $<0.5 \%$ and given as numbers). c) Element ratios as obtained from XRF core scanning. Upper panel: Ti/AI (black) and Ti/K (orange) ratios; lower panel: $\mathrm{Ca} / \mathrm{Fe}$ ratios (gray) as well as the 3-point moving average of the bulk percentages of $\mathrm{CaCO}_{3}$ (purple) and total organic carbon (green) from Syring et al. (2020). 
The element ratios Ti/Al and Ti/K which are indicative of terrigenous input remain stable throughout the sediment record, with a significant increase in counts only during the last 200 years. The $\mathrm{Ca} / \mathrm{Fe}$ ratios reveal a trend similar to the benthic and planktic foraminiferal flux rates (Fig. 3c, d \& Fig. 5c). Highest $\mathrm{Ca} / \mathrm{Fe}$ ratios ( 0.4$)$ occurred between 10.6 and $7.8 \mathrm{ka}$, followed by a decrease until ca. $5.5 \mathrm{ka}$. Afterwards, the record is shaped by low and almost constant values around 0.15 (Fig. 5c).

\subsection{Grain sizes}

The measured sortable silt mean grain size $(\overline{S S})$ varies between 17.5 and $31.5 \mu \mathrm{m}$ in the studied record (Fig. 6a). A check for ice-rafted debris influence after Hass (2002) shows a correlation between the sand fraction and sortable silt values $\left(R^{2}=0.81\right)$. Thus, ice-rafted debris forms part of the silt fraction and misinterpretations regarding the current strength are possible (cf. Hass, 2002). The calculated $\Delta \overline{S S}$ curve, which can be interpreted in terms of relative current-speed fluctuations (Hass, 2002), reveals predominantly higher values/coarser grains between 10.0 and $5.0 \mathrm{ka}$ and lower values/finer grains afterwards (Fig. 6a).

[insert Fig. 6]

Fig. 6: a) Sortable silt values of PS93/025. b) Selected grain size distribution curves. Black arrows indicate trends seen towards younger ages. c) Detailed overview of the displayed grain size distribution curves, showing the shift from a coarse-silt to a medium-silt mode. Figures are shown in chronological order from old (lower right) to young (upper left).

The grain size distribution curves display a visible trend from coarser grain sizes in the Early Holocene to finer grain sizes in the Late Holocene, beginning with a decreasing mode in the coarse-silt range around $35 \mu \mathrm{m}$ and ending with an increasing mode in the medium-silt range around $15 \mu \mathrm{m}$. The transition can be found between ca. 6.0 and 5.0 ka through the temporal appearance of bimodal shaped distribution curves.

All data sets presented in this paper are available at www.pangaea.de.

\section{Discussion}

\subsection{Early to mid-Holocene environmental conditions (10.6-5 ka)}

The homogeneity of sediments at the core base and the dating of a marine bivalve found at $260 \mathrm{~cm}$ demonstrate that the outermost NE Greenland shelf was free of grounded ice at $10.6 \mathrm{ka}$, the age of the core base, according to the age model preferred here. This is in line with the oldest reliable dating result from marine deposits on NE Kronprins Christian Land $\left(\mathrm{KCL}, 81^{\circ} 10^{\prime} \mathrm{N}\right)$, close to the shelf break, which suggests an ice-free coast as early as $11.1 \mathrm{ka}$ (converted from ${ }^{14} \mathrm{C}$ age reported by Hjort, 1997). Most datings of marine deposits (beach walls) from shores of NE Greenland $\left(79-81^{\circ} \mathrm{N}\right)$ are younger than our core base and range between 9 and $10 \mathrm{ka}$ (Bennike and Björck, 2002). However, recent reconstructions based on ${ }^{10} \mathrm{Be}$ datings from the outermost islands off the Greenland coast slightly 
further south $\left(78-79^{\circ} \mathrm{N}\right)$ suggest that the NE Greenland shelf was deglaciated already $\sim 11.5 \mathrm{ka}$ (Larsen et al., 2018). Since core PS93/025 did not penetrate any till that may be expected to underly the marine sediments recovered in our core, our result can be regarded as a minimum age for the deglaciation of the shelf, supporting earlier reconstructions.

The planktic foraminiferal assemblage of the sediment record is characterized by a dominance of the polar species $N$. pachyderma (>80\%) and only minor amounts of the subpolar species $T$. quinqueloba (around 5-10\%) which appears almost continuously only until 5.6 ka (Fig. 3e). Pados and Spielhagen (2014) showed that this relation is the general distribution in the modern western Fram Strait, whereas T. quinqueloba shows higher abundances (up to 40\%) further east within the warmer and more saline WSC. Since the abundances of subpolar foraminifers, particularly T. quinqueloba, in the Fram Strait region, have been linked semiquantitatively to the advection of warmer Atlantic Water (e.g., Carstens et al., 1997; Pados and Spielhagen, 2014; Volkmann, 2000), a persisting but variable inflow until 5.6 ka via the RAC can be concluded from the continuous presence of subpolar species in sediments from this interval. According to sea level reconstructions on both sides of KCL (Fig. 1a) the coastal areas near site PS93/025 were at least $80 \mathrm{~m}$ lower in the Early Holocene, due to isostatic depression (Hjort,1997; Strunk et al., 2018). The extent of the Late Weichselian ice sheet on the NE Greenland shelf is still under discussion (Strunk et al., 2018). However, a relative sea level several tens of meters higher than today at our site can be expected from the proximity to KCL. This would have increased the water depth on the outer shelf and allowed a relatively strong subsurface AW advection to site PS93/025. According to the sea level reconstructions from KCL, the isostatic rebound had lowered the relative sea level by $\sim 20-40 \mathrm{~m}$ around $8 \mathrm{ka}$, keeping the excess water depth well above the presentday value. Proportions of the subpolar T. quinqueloba in a core from further south (core PS1230-1; Bauch et al., 2001a) display a similar trend as in PS93/025 (Fig. 3e). The same applies to percentages of T. quinqueloba near Svalbard (cores MSM5/5-712-2 and MSM5/5-723-2; Werner et al., 2013, 2016). The proportions found in our record consequently indicate a positioning of the study site right within the area influenced by RAW (see Return Atlantic Current, Fig. 1a).

Planktic and benthic foraminiferal fluxes and the $\mathrm{Ca} / \mathrm{Fe}$ element ratio show highest values between 10.6 and $\sim 8.0 \mathrm{ka}$, with a considerable variability (Fig. 3c, d \& 5c). Highest flux rates likely relate to maxima in productivity of carbonate producing organisms (mainly foraminifers and coccoliths) since food availability is one of the major controls (Carstens et al., 1997; Jonkers et al., 2010). The Ca/Fe ratio is considered a general proxy for paleoproductivity (Vare et al., 2009) and supports this assertion. In combination with low values of the sea-ice indicating $\mathrm{P}_{\mathrm{III}} \mathrm{P}_{25}$ index (Fig. $3 \mathrm{~d}$ ), the proxies suggest that the study site was either completely ice-free in summer or under a reduced to variable sea-ice cover until $\sim 8.0 \mathrm{ka}$, in an interval that roughly correlates to the Greenlandian stage of the Holocene subdivision (11.7-8.2 ka; Walker et al., 2018). According to the age model applied here, the environmentally favorable period was punctuated by at least two short intervals ( 200 years) with lower flux rates at $\sim 8.2$ and $\sim 8.7 \mathrm{ka}$. Syring et al. (2020) suggest increased sea-ice conditions and strongly reduced phytoplankton productivity for these intervals and our results are in line with this. The overall relatively high planktic foraminiferal fragmentation values between 10.6 and 8.0 ka (Fig. 3b) are likely related to dissolution and mechanical breakage. We speculate that dissolution was enhanced by organic carbon oxidation in the course of an increased accumulation of organic matter (cf. Archer et 
al., 1989; Emerson and Archer, 1990) resulting from high primary productivity as proposed by Syring et al. (2020).

Flux rates of ice-rafted debris were high between 10.6 and $8.3 \mathrm{ka}$, while showing an overall trend to lower values (Fig. 5a). The high values likely resulted from the presence and melting of icebergs, caused by the advection of warmer AW, the latter being indicated by high foraminiferal fluxes and the occurrence of the subpolar foraminifer species $T$. quinqueloba. The proportion of rounded grains is rather low at 10.6-8.6 $\mathrm{ka} \mathrm{(45 \% )} \mathrm{and} \mathrm{8.4-5.2} \mathrm{ka} \mathrm{(40 \% ),} \mathrm{compared} \mathrm{to} \mathrm{other} \mathrm{parts} \mathrm{of} \mathrm{the} \mathrm{record} \mathrm{(Fig.} \mathrm{5a).}$ In general, sub-rounded to rounded grains are typical for sea-ice-rafted debris (SIRD), while icebergrafted debris (IRD) is usually dominated by angular grains (e.g., Dunhill, 1998; St John et al., 2015). Lower percentages of rounded grains may therefore indicate a lower sea-ice-to-iceberg ratio. This is in line with low values of the sea-ice indicating $P_{I I I} P_{25}$ index at our site (Syring et al., 2020) which suggest a reduced but somewhat variable sea-ice cover until approximately $5.0 \mathrm{ka}$. Most of the icerafted debris is composed of crystalline rocks, quartz and feldspar. Percentages of clastic sedimentary rocks, limestones and dolomites are rather low (Fig. 5b). There are basically two major source areas for ice-rafted erratics in Holocene Arctic sediments: The partly glaciated Eurasian archipelagos (Svalbard, Franz Josef Land, Novaya Zemlya, Severnaya Zemlya) and the Canadian Arctic Archipelago plus Northern Greenland. Clasts originating from the Canadian Arctic Islands are dominated by dolomites and limestones and transported by the clockwise Beaufort Gyre (Phillips and Grantz, 2001). On the contrary, quartz, chert, sandstone and siltstone characterize the erratics from the Eurasian archipelagos. They are transported via the Transpolar Drift (TD) and concentrations of carbonate clasts are low. Nürnberg et al. (1994) studied the sediment along the TD and showed that also the terrigenous components in sea-ice and shelf sediments are dominated by quartz, feldspar, rock fragments, mica and clay. Hence, the ice-rafted debris in our record, which shows high proportions of quartz and mica and only very low percentages of limestones and dolomites $(<0.5 \%)$, probably originate from sediment sources associated with the TD pattern. Sediment supply from local sources (NE Greenland), namely the Proterozoic and Phanerozoic Red Beds (Bond and Lotti, 1995), seems neglectable since hardly any reddish clastic rock fragments were found. They were probably transported southward along the coast and therefore did not reach the core site (Fig. 1a) due to the ice drift pattern which is largely sub-parallel to the continental margin (Vinje and Finnekåsa, 1986). The uniform distribution of the terrigenous element ratios Ti/Al and Ti/K (Fig. 5c) further indicates that the source region of the deposited terrigenous sediment components remained stable throughout the last -10.6 ka. Since quartz grains are characteristic for the terrigenous coarse fraction found in sea-ice from the Eurasian Basin and the surrounding shelf regions (Nürnberg et al., 1994), the lower share of crystalline rocks, quartz and feldspar (mainly quartz) during Early and mid-Holocene indicates lower quantities of sea-ice sediments at this time. Further south (site PS1230; Bauch et al., 2001a), Holocene IRD flux rates were lower than at site PS93/025 and with only minor variability after $9.7 \mathrm{ka}$ (Fig. 5a). Apparently, only lower quantities of sand-sized lithic particles were transported that far south.

Between 10.6 and $6 \mathrm{ka}$, the grain size distribution curves are characterized by a decreasing peak around $35 \mu \mathrm{m}$ (coarse silt), while also showing a flat shoulder in the fine and medium silt range. $A$ second peak around $15 \mu \mathrm{m}$ (medium silt) becomes apparent after 7 ka (Fig. 6b, c). While iceberg- 
transported sediments can range from boulder-size material to fine-grained silt and clay, sea-ice sediments are dominated by silt and clay (Clark and Hanson, 1983; Nürnberg et al., 1994). Since the share of grains $>63 \mu \mathrm{m}$, which are regarded as typical for iceberg deposits, is rather low within our grain size distribution curves, we infer that the contribution of icebergs to the deposited sediment during the Holocene was also overall low and decreasing with time. According to the classification of Clark and Hanson (1983), the sediments until 6.0 ka are of Type 1 (non-sorted, clay and silt), representing sea-ice and iceberg deposition. The visible decline of the coarse-silt mode can be interpreted as a successive reduction of iceberg deposition, which may have been related both to the ice recession on land and the decreasing water depth at our site, resulting from isostatic rebound of the shelf (cf. Hjort, 1997). The latter may have successively decreased the number of large icebergs from the Arctic Ocean reaching site PS93/025 because the area was protected by the increasingly shallowing banks to the north of it which limited the drift of icebergs across the core site. Bimodal shaped grain size distribution curves, appearing between ca. 6.0 and $5.0 \mathrm{ka}$, mark a transition to a different type of sediment deposition thereafter.

The IRD-corrected $\Delta \overline{S S}$ sortable silt curve is a proxy for bottom current strength variations (Hass, 2002). Between 10.0 and 5.0 ka the $\Delta \overline{S S}$ curve tends towards coarser grains (Fig. 6a), suggesting comparatively strong bottom currents, possibly due to Atlantic Water advection. Highest $\Delta \overline{S S}$ values and therefore strongest bottom currents apparently occurred between 9.8 and $6.6 \mathrm{ka}$. Again, this may have been an effect of the postglacial isostatic rebound of the NE Greenland region which may have successively decreased the thickness of the AW layer on the outer shelf during the investigated time interval. Consequently, the higher relative sea level during the Early Holocene allowed a relatively strong advection of AW to the core site which is in line with the mentioned stronger bottom currents.

The $\delta^{18} \mathrm{O}$ values of benthic $C$. neoteretis are low (4.5-4\%) between 10.6 and 8.0 ka while showing a slow but steady decrease (Fig. 4d). Low $\delta^{18} \mathrm{O}$ values likely indicate relatively high calcification temperatures (cf. Epstein et al., 1953), linked to the inflow of Atlantic Water, as discussed above. Planktic $\delta^{18} \mathrm{O}$ values of $N$. pachyderma vary around $4.2 \%$ between 10.6 and $7.8 \mathrm{ka}$. The rather low and stable benthic and planktic values with little internal variability until $\sim 8$ ka reflect stable subsurface conditions. Further, the minimal difference between planktic and benthic $\delta^{18} \mathrm{O}$ suggests a relatively thick and homogeneous AW water mass on the outer NE Greenland shelf in the Early Holocene, when the water depth was significantly greater (cf. Hjort, 1997). Since it seems unlikely that there was no vertical temperature gradient in this water mass, we speculate that differences between benthic and planktic habitat depths were balanced isotopically by an upwards increasing influence of isotopically light freshwater in the near-surface parts of the AW layer. The $\delta^{13} \mathrm{C}$ values of $C$. neoteretis display a general trend to higher values throughout the sediment record (Fig. 4c), with only one major setback. Low and slowly rising benthic $\delta^{13} \mathrm{C}$ values (-0.8 to $-0.2 \%$ ) between 10.6 and $\sim 8.0$ ka probably relate to the high level of bioproductivity in the upper water column (cf. Syring et al., 2020), as discussed above, and the decomposition of isotopically light organic carbon, resulting in low $\delta^{13} \mathrm{C}$ values in the lower part of the water column. The $\delta^{13} \mathrm{C}$ values of planktic $N$. pachyderma were low in the Early Holocene part of our record (Fig. 4a). Today, $\delta^{13} \mathrm{C}$ values of dissolved inorganic carbon (DIC) in western Fram Strait waters are highest in the upper $100 \mathrm{~m}$ (Pados et al., 2015). Further, a recent synoptic study revealed sea-ice coverage and the depth of the chlorophyll maximum as the major 
factors determining the vertical habitat of this species (Greco et al., 2019). Considering the evidence for a reduced sea-ice cover (Syring et al., 2020) and strong bioproduction (cf. foraminifer fluxes; Fig. $3 \mathrm{c}, \mathrm{d}$ ) before $\sim 8 \mathrm{ka}$, we suppose that $N$. pachyderma on average could obtain a relatively deep habitat with low $\delta^{13} \mathrm{C}$ of the DIC, similar to the situation today in the central Fram Strait under the influence of the RAC (cf. Pados and Spielhagen, 2014). Two pronounced planktic $\delta^{13} \mathrm{C}$ minima around 10.0 and 8.2 ka may indicate short periods of reduced ventilation of these subsurface waters. Werner et al. (2013) found evidence for cooler and probably reduced northward advection of AW to the eastern Fram Strait around $8.2 \mathrm{ka}$ and correlated this to the hemisphere-wide cool $8.2 \mathrm{ka}$ event. Assuming a causal connection of cool events in the eastern and western Fram Strait, our data point to a weaker RAC flow during this event. No correlating event is found at $10.0 \mathrm{ka}$ in the eastern Fram Strait and thus the cause of low planktic $\delta^{13} \mathrm{C}$ values in the western Fram Strait at this time remains enigmatic.

A rapid drop of benthic $\delta^{13} \mathrm{C}$ values at $-8.0-7.2 \mathrm{ka}$ (Fig. 4c) which was coeval with a decrease in benthic foraminifer fluxes by $>50 \%$, a significant decrease in the fragmentation index (Fig. 3b, c), and an increase in benthic $\delta^{18} \mathrm{O}$ (Fig. 4d) reflect a drastic reorganization of bottom water conditions. We interpret these data as indicating a reduction in both AW advection and temperature as well as bottom water ventilation, at a time when near-surface productivity was decreasing due to the higher sea-ice coverage revealed by higher values of the $\mathrm{P}_{\mathrm{III}} \mathrm{P}_{25}$ index (cf. Fig. $3 \mathrm{~d}$ ). From 7.2 until 4.3 ka, benthic $\delta^{13} \mathrm{C}$ values were rising from a low level (below $-0.8 \%$ ) to Late Holocene values of ca. $-0.3 \%$ (Fig. $4 \mathrm{C}$ ). The high benthic $\delta^{18} \mathrm{O}$ values during this time point to lower temperatures near the sea floor than in the Early Holocene, resulting from the advection of less and cooler AW. In line with this, the slowly rising benthic $\delta^{13} \mathrm{C}$ values may be explained by a combined effect of the decreasing relative sea level and the relatively low productivity under a sea-ice coverage which was significantly higher than before (cf. Syring et al., 2020). The latter should have led to less decomposition of isotopically light organic carbon and consequently rising $\delta^{13} \mathrm{C}$ values. Moreover, the postglacial isostatic rebound of the $\mathrm{NE}$ Greenland shelf ( $50 \mathrm{~m}$ between 8 and $4 \mathrm{ka}$; Hjort, 1997) may have lifted the sea floor at site PS93/025 from the AW-dominated domain to a depth more influenced by Polar/Shelf Water (cf. Fig. 1) which has relatively high $\delta^{13} \mathrm{C}$ values (cf. Pados et al., 2015). We note that the change from relatively high $(-30 \%)$ to low $(<20 \%)$ fragmentation around $8 \mathrm{ka}$ in our core is opposite to what is observed in the deep Fram Strait (cf. Zamelczyk et al., 2012). We refrain from a further discussion here, because shelf and deep-sea environments may have been considerably different.

Planktic $\delta^{18} \mathrm{O}$ values vary around $4.0 \%$ between 7.8 and $4.1 \mathrm{ka}$ (Fig. $4 \mathrm{~b}$ ). The higher variability compared to before in both planktic and benthic $\delta^{18} \mathrm{O}$ records likely indicates strong fluctuations of $\mathrm{AW}$ advection with periods of weakened inflow of warm water masses and therefore lower salinity. After $\sim 7.2 \mathrm{ka}$, the benthic-planktic $\delta^{18} \mathrm{O}$ difference (Fig. 4e) is higher than before $(\sim 0.5 \%$ ), pointing towards a stronger vertical stratification. This is likely resulting from a reduced advection of AW and a freshening of the (sub)surface waters, related to an increase in sea-ice cover. Low and stable planktic $\delta^{18} \mathrm{O}$ values of $N$. pachyderma were also found in the eastern Fram Strait until $7.2 \mathrm{ka}$ (core MSM5/5712-2; Werner et al., 2013) (Fig. 4b) and (considering also evidence from planktic foraminifer associations) interpreted to reveal a strong and warm AW advection from the south. In the same core, higher and more variable values thereafter were linked to cooler temperatures in the subsurface water masses (Werner et al., 2013). The similarity of changes, though showing a temporal offset, suggests 
that site PS93/025 was bathed in waters transported by the RAC throughout the Early Holocene. However, the period of stable and strong AW advection was apparently terminated in the NW Fram Strait $\sim 800$ years earlier than off Svalbard. In contrast to the decreasing benthic ones, $\delta^{13} \mathrm{C}$ values of $N$. pachyderma were rising after $\sim 8.1 \mathrm{ka}$, from Early Holocene values of $0.2-0.4 \%$ to the mid-Holocene level of $0.6-0.8 \%$ which was reached at $-6.9 \mathrm{ka}$. (Fig. $4 \mathrm{a}$ ). We interpret this increase to reflect a change in the preferred habitat of $N$. pachyderma. Since there is biomarker evidence for an increase in sea-ice coverage (Syring et al., 2020) and a decrease in bioproduction (cf. foraminifer fluxes; Fig. 3c, d) at $\sim 8.0 \mathrm{ka}$, we suppose that $N$. pachyderma followed the phytoplankton food to shallower, better ventilated waters. Between 7 and $\sim 3.0 \mathrm{ka}$, a planktic $\delta^{13} \mathrm{C}$ plateau with high values $(\sim 0.7 \%)$ can be found in our record (Fig. 4a). Comparable intervals with high $\delta^{13} \mathrm{C}$ values are common in many Holocene records from the entire Nordic Seas (e.g., Bauch and Weinelt, 1997; Risebrobakken et al., 2011; Sarnthein et al., 2003; Telesiński et al., 2014; Werner et al., 2013) and display the same timing. This widespread occurrence implies that some paleoenvironmental parameters (e.g., good ventilation of subsurface waters) were similar and stable during this time period. Since sea-ice largely prevents atmosphere-ocean gas exchange in the central Arctic Ocean, ventilation of waters on the open shelves is crucial for the $\delta^{13} \mathrm{C}$ values of the subsurface water mass in the Arctic (Spielhagen and Erlenkeuser, 1994). This isotopic signature shows only little change en route under the transpolar seaice drift. Lubinski et al., (2001) proposed that, through continuous flooding of the shelf regions in the mid-Holocene (cf. Bauch et al., 2001b), well-ventilated shelf waters with high $\delta^{13} \mathrm{C}$ values were transported to the Arctic Ocean. Our finding of high planktic $\delta^{13} \mathrm{C}$ values in the NW Fram Strait throughout the mid-Holocene supports this hypothesis and suggests that well-ventilated waters with high $\delta^{13} \mathrm{C}$ reached the NW Fram Strait continuously from 7 to $3 \mathrm{ka}$.

\subsection{Mid- to Late Holocene environmental conditions (5 ka until present)}

From a number of the proxy data sets presented here we can conclude that conditions off NE Greenland were different than before and environmentally less favorable. Foraminiferal parameters reach very low values at 6-5 ka and mostly remain on this level. Flux rates are an order of magnitude lower compared to 10.6-8 ka and reach values close to zero after $\sim 4.4 \mathrm{ka}$ (Fig. 3c, d). Subpolar $T$. quinqueloba are almost absent after $4.6 \mathrm{ka}$ (Fig. 3e). Furthermore, the $\mathrm{Ca} / \mathrm{Fe}$ element ratio is relatively low after $5.5 \mathrm{ka}$ (Fig. $5 \mathrm{C}$ ). Together, these data indicate that productivity was very limited after $\sim 5.0 \mathrm{ka}$, likely because of the higher and/or seasonally more extended sea-ice coverage which is suggested by the higher values of the $P_{I I I I} P_{25}$ sea-ice index (Fig. 3d). After $5.0 \mathrm{ka}$, also planktic foraminiferal fragmentation is low (Fig. 3b), pointing at weak carbonate dissolution due to less organic carbon oxidation and neglectable mechanical breakage from terrigenous input. Similar to our site, planktic foraminiferal fluxes in the eastern Fram Strait (core MSM5/5-712-2; Werner et al., 2013) display a shift to rather low values after $5.2 \mathrm{ka}$. Werner et al. (2013) attributed this shift to a transition to cold conditions starting at $5.2 \mathrm{ka}$, induced by an increased southward expansion of the sea-ice margin and lower insolation. Funder et al. (2011) used the abundance of dated driftwood transported by sea-ice found on North Greenland shores as a proxy for multiyear sea-ice and found a clear transition to colder conditions after $6.0 \mathrm{ka}$, with more sea-ice. Accordingly, a pronounced trend to colder conditions coupled with a higher and/or seasonally more extended sea-ice coverage can be seen after $\sim 6-5 \mathrm{ka}$ 
on both sides of the Fram Strait. Together, these findings suggest the mid-Holocene as a time when, under successively decreasing insolation (Fig. 3a), climate shifted to a generally colder state in the Fram Strait area, with very weak AW advection by the RAC and with more sea-ice. Apparently, these were the average paleoenvironmental conditions in pre-industrial times, before the onset of modern Arctic warming. Our results do not show evidence for significant changes occurring at the boundary between the Northgrippian and Maghalayan stages of the Holocene (4.2 ka; cf. Walker et al., 2018).

The sedimentological parameters from sediments deposited after 6-5 ka support the conclusions drawn from micropaleontological data. The ice-rafted debris flux rates remained low after $\sim 4.0 \mathrm{ka}$ (Fig. $5 a)$. This may be related to less melting under colder conditions and/or a higher sea-ice coverage in general, but also to less icebergs reaching our site. The latter is indicated also by the increase of rounded grains after $5.2 \mathrm{ka}$ and the increase of quartz grains within the ice-rafted debris after $4.8 \mathrm{ka}$ (Fig. 5a) which both point to higher relative proportions of sediment deposited by sea-ice (cf. Nürnberg et al., 1994; Dunhill, 1998; St John et al., 2015). Moreover, grain size distribution curves show an increasing mode in the medium-silt range around $15 \mu \mathrm{m}$ and only small amounts of coarser grains after 5.0 ka (Fig. 6b, c) which both are characteristic for sea-ice deposition (cf. Clark and Hanson, 1983). After $5 \mathrm{ka}$, the trend of the $\Delta \overline{S S}$ record towards finer grains implies weaker bottom currents than before, possibly related to a decreasing Atlantic Water advection.

Our benthic and planktic $\delta^{18} \mathrm{O}$ values of $C$. neoteretis and $N$. pachyderma are generally higher during the Late Holocene than before (Fig. 4b, d). Considering the evidence presented above, these values corroborate the proposed colder conditions with weak AW advection and a higher sea-ice coverage. Higher benthic and planktic $\delta^{13} \mathrm{C}$ values during the mid- and Late Holocene may reflect the weak influence of $\mathrm{AW}$ with a lower $\delta^{13} \mathrm{C}$ signature and the advection of well-ventilated shelf waters from the Arctic Ocean with relatively high $\delta^{13} \mathrm{C}$ values (cf. Lubinski et al., 2001; Spielhagen and Erlenkeuser, 1994).

Microfossil and isotope records from the last $\sim 2 \mathrm{ka}$ at site PS93/025 have to be treated with some caution because the numbers of foraminifers found in our samples were rather low so that, in a number of cases, foraminifers had to be collected from larger sample intervals (up to $5 \mathrm{~cm}$ ) to obtain isotope data. Nevertheless, around $2.2 \mathrm{ka}$, and between 1.2 and $0.3 \mathrm{ka}$, mainly benthic and to some extent also planktic foraminiferal flux rates show slightly higher values than before, in between, and after (Fig. 3c). This may point to some environmental amelioration for benthic and planktic foraminifers, possibly due to a stronger inflow of warm AW. The latter is indicated by the reoccurrence of the subpolar planktic foraminifer T. quinqueloba which was absent after $4.6 \mathrm{ka}$ and reappears from 2.4 to $2.0 \mathrm{ka}$ and from 1.6 to $1.0 \mathrm{ka}$, matching the mentioned intervals of higher foraminiferal flux rates at our site. While there is only little information available on environmental variations off NE Greenland on centennial timescales, several high-resolution paleoenvironmental data sets based on microfossil investigations were published from cores along the eastern Barents Sea and Svalbard continental margin (e.g., Dylmer et al., 2013; Hald et al., 2007; Jernas et al., 2013; Sarnthein et al., 2003; Spielhagen et al., 2011). Although there are some differences in the timing of warm events as reconstructed from different microfossil groups (cf. Matul et al., 2018, for a comparative study), there is a general agreement on the identification of the Roman Warm Period (RWP, around $2 \mathrm{ka}$ ) and the Medieval Climate Anomaly (MCA, around $0.9 \mathrm{ka}$ ) as periods with an increased northward advection of 
AW to the Fram Strait area. Even with some stratigraphic uncertainty in the youngest part of our record, our data from PS93/25 place the foraminiferal evidence for a slightly enhanced advection of AW by the RAC in the same time frame (Fig. 3c) and identify the RWP and the MCA as Fram Straitwide warming events.

Despite the limitations resulting from the sparseness of foraminifers, some features in our planktic and benthic isotope records still deserve attention. Pronounced peaks of lower planktic and benthic $\delta^{18} \mathrm{O}$ and $\delta^{13} \mathrm{C}$ values around 2.0 and $1.0 \mathrm{ka}$ (Fig. 4, red bars) roughly correlate with the previously mentioned intervals of higher foraminiferal flux rates and higher percentages of $T$. quinqueloba (Fig. 3). Considering the microfossil evidence, the lower $\delta^{18} \mathrm{O}$ values may indicate comparatively warmer water masses, whereas low $\delta^{13} \mathrm{C}$ values may point to reduced ventilation due to enhanced stratification resulting from stronger salinity differences between surface waters and subsurface AW. Accordingly, the isotope data corroborate the hypothesis of an increased inflow of warm RAW at these times. Extraordinarily low planktic and benthic $\delta^{18} \mathrm{O}$ and $\delta^{13} \mathrm{C}$ values characterize the record from the last $\sim 200$ years (i.e., the Modern/Industrial Period; Fig. 4). While the low planktic $\delta^{18} \mathrm{O}$ values may result from a lower salinity due to low- $\delta^{18} \mathrm{O}$ meltwater discharge from NE Greenland glaciers, low benthic values may again indicate an enhanced advection of warmer RAW onto the NE Greenland shelf. Olsen and Ninnemann (2010) attributed the low $\delta^{13} \mathrm{C}$ values in modern water masses, which are strongly departing from pre-industrial values, to the Suess effect, i.e., an overprint by isotopically light carbon dioxide from anthropogenic emissions. This effect may also explain the low $\delta^{13} \mathrm{C}$ values in the very youngest part of our record. Similar low $\delta^{13} \mathrm{C}$ values were also recorded from the last $\sim 100$ years in the eastern Fram Strait (Werner et al., 2011). Unfortunately, the very low numbers of foraminifers in the very youngest part of our sediment record do not allow to reconstruct in detail the imprint of Arctic warming during the last 100-150 years on the water mass parameters off NE Greenland.

\section{Conclusions}

New proxy data records from core PS93/025 provide improved insights into the sea-ice history and the Atlantic-derived heat transfer to the western Fram Strait off NE Greenland during the past $10.6 \mathrm{ka}$. Foraminiferal associations as well as flux and fragmentation data, combined with $\mathrm{Ca} / \mathrm{Fe}$ ratios and foraminiferal stable isotope records reveal a maximum in bioproductivity between 10.6 and $\sim 8.0 \mathrm{ka}$ due to a strong advection of warmer Atlantic Water crossing the Fram Strait as the Return Atlantic Current. Grain size data reveal relatively strong bottom currents and a significant contribution of iceberg-rafted debris to the sediment deposition. Both features may be related to the isostatically depressed sea floor and the related greater water depth at our site which should have allowed a penetration of both Atlantic Water and large icebergs closer to the modern coastline than today. There is no evidence for a strong contribution of icebergs from northern North America to the deposition of lithogenic particles at our site. Instead, the ice-rafted debris in our record probably originate from sediment sources associated with the Transpolar Drift pattern.

Our proxy data indicate a decrease of AW inflow and a higher sea-ice coverage together with weakened bioproductivity and less sedimentation from icebergs after $\sim 8.0$ ka. However, 
micropaleontological and sedimentological data indicate a lasting influence of AW advection onto a shallowing shelf until $\sim 5.0 \mathrm{ka}$.

A significant paleoenvironmental change at our site, i.e., offshore NE Greenland, occurred around 5.0 ka. All data sets unequivocally point towards colder conditions with a higher and/or seasonally more extended sea-ice coverage during the Late Holocene. Micropaleontological and isotopic data indicate two intervals of re-increased AW advection around $\sim 2.0$ and $\sim 1.0 \mathrm{ka}$, which may correlate with the Roman Warm Period and the Medieval Climate Anomaly, respectively.

\section{Acknowledgements}

This work is a contribution to the ECHONEG (Environmental and Climate History Off North-East Greenland) research project financed by the German Research Foundation (DFG). We thank the science party and crew onboard RV Polarstern during the expedition PS93.1 for retrieving the investigated sediment record. Furthermore, we appreciate the work of Hendrik Grotheer and Gesine Mollenhauer from the AWI MICADAS Laboratory Bremerhaven and Christian Hamann from the Leibniz Laboratory of Kiel University, who performed most of the AMS radiocarbon datings. For the stable isotope measurements, we are grateful to Dirk Nürnberg and Sebastian Fessler from the GEOMAR Isotope Laboratory. Ingrid Leirvik Olsen and Sigrun Marte Kvendbø Hegstad performed the XRF core scanning at the UiT The Arctic University of Norway. This article greatly benefited from the constructive reviews by Katrine Husum and one anonymous reviewer. The study used samples and data provided by AWI (grant number AWI PS93.1_1).

\section{Data}

Corresponding data is available at www.pangaea.de.

\section{References}

Aagaard-Sørensen S, Husum K, Werner K, Spielhagen RF, Hald M, Marchitto TM (2014) A Late Glacial-Early Holocene multiproxy record from the eastern Fram Strait, Polar North Atlantic. Marine Geology 355: 15-26. DOI: https://doi.org/10.1016/j.margeo.2014.05.009

Archer D, Emerson S, Reimers C (1989) Dissolution of calcite in deep-sea sediments: pH and O2 microelectrode results. Geochimica Cosmochimica Acta 53: 2831-2845. DOI: https://doi.org/10.1016/0016-7037(89)90161-0

Bauch HA, Erlenkeuser H, Spielhagen RF, Struck U, Matthiessen J, Thiede J, Heinemeier J (2001a) A multiproxy reconstruction of the evolution of deep and surface waters in the subarctic Nordic seas over the last 30,000 yr. Quaternary Science Reviews 20: 659-678. DOI: https://doi.org/10.1016/S02773791(00)00098-6

Bauch HA, Müller-Lupp T, Taldenkova E, Spielhagen RF, Kassens H, Grootes PM, Thiede J, Heinemeier J, Petryashov VV (2001b) Chronology of the Holocene transgression at the North Siberian margin. Global and Planetary Change 31 (1-4): 125-139. DOI: https://doi.org/10.1016/S0921- 


\section{1(01)00116-3}

Bauch HA, Weinelt MS (1997) Surface water changes in the norwegian sea during last deglacial and holocene times. Quaternary Science Reviews 16: 1115-1124. DOI: https://doi.org/10.1016/S02773791(96)00075-3

Bennike O, Björck S (2002) Chronology of the last recession of the Greenland Ice Sheet. Journal of Quaternary Science 17 (3): 211-219 DOI: https://doi.org/10.1002/jqs.670

Beszczynska-Möller A, Fahrbach E, Schauer U, Hansen E (2012) Variability in Atlantic water temperature and transport at the entrance to the Arctic Ocean, 1997-2010. ICES Journal Of Marine Science 69: 852-863. DOI: https://doi.org/10.1093/icesjms/fss056

Bond GC, Lotti R (1995) Iceberg Discharges into the North Atlantic on Millennial Time Scales During the Last Glaciation. Science 267: 1005-1010. DOI: https://doi.org/10.1126/science.267.5200.1005

Carstens J, Hebbeln D, Wefer G (1997) Distribution of planktic foraminifera at the ice margin in the Arctic (Fram Strait). Marine Micropaleontology 29: 257-269. DOI: https://doi.org/10.1016/S03778398(96)00014-X

Clark DL, Hanson A (1983) Central Arctic Ocean Sediment Texture: A Key to Ice Transport Mechanisms. In: Molnia BF (ed) Glacial-Marine Sedimentation. Boston: Springer, pp. 301-330. DOI: https://doi.org/10.1007/978-1-4613-3793-5_7

Condron A, Winsor P (2012) Meltwater routing and the Younger Dryas. Proceedings of the National Academy of Sciences 109 (49): 19928-19933. DOI: https://doi.org/10.1073/pnas.1207381109

Croudace IW, Rindby A, Rothwell RG (2006) ITRAX: description and evaluation of a new multifunction X-ray core scanner. Geological Society, London, Special Publications 267: 51-63. DOI: https://doi.org/10.1144/GSL.SP.2006.267.01.04

Darling KF, Kucera M, Kroon D, Wade CM (2006) A resolution for the coiling direction paradox in Neogloboquadrina pachyderma. Paleoceanography 21: 1-14. DOI: https://doi.org/10.1029/2005PA001189

Dunhill G (1998) Comparison of sea-ice rafted debris and glacial-ice rafted debris: grain size, surface features, and grain shape. Open-File Report 98-367, USGS Numbered Series. U.S. Geological Survey. Available at: http://pubs.er.usgs.gov/publication/ofr98367 (accessed 20 July 2018)

Dylmer CV, Giraudeau J, Eynaud F, Husum K, De Vernal A (2013) Northward advection of Atlantic water in the eastern Nordic Seas over the last 3000 yr. Climate of the Past 9: 1505-1518. DOI: https://doi.org/10.5194/cp-9-1505-2013

Emerson SR, Archer D (1990) Calcium carbonate preservation in the ocean. Philosophical Transactions of the Royal Society of London. Series A, Mathematical and Physical Sciences 331: 2940. DOI: https://doi.org/10.1098/rsta.1990.0054

Epstein S, Buchsbaum R, Lowenstam HA, Urey HC (1953) Revised carbonate-water isotopic temperature scale. Geological Society of America Bulletin 64: 1315-1325. DOI: https://doi.org/10.1130/0016-7606(1953)64[1315:RCITS]2.0.CO;2

Funder S, Goosse H, Jepsen H, Kaas E, Kjær KH, Korsgaard NJ, Larsen NK, Linderson H, Lyså A, Möller P, Olsen J, Willerslev E (2011) A 10,000-Year Record of Arctic Ocean Sea-Ice Variability - View from the Beach. Science 333: 747-750. DOI: https://doi.org/10.1126/science.1202760

Gascard J-C, Richez C, Rouault C (1995) New Insights on Large-Scale Oceanography in Fram Strait: 
The West Spitsbergen Current. In: Grebmeir JM and Smith WO Jr (eds) Arctic Oceanography: Marginal Ice Zones and Continental Shelves. Washington, DC: American Geophysical Union (AGU), pp. 131-182. DOI: https://doi.org/10.1029/CE049p0131

Greco M, Jonkers L, Kretschmer K, Bijma J, Kucera M (2019) Depth habitat of the planktonic foraminifera Neogloboquadrina pachyderma in the northern high latitudes explained by sea-ice and chlorophyll concentrations. Biogeosciences 16: 3425-3437. DOI: https://doi.org/10.5194/bg-16-34252019

Hald M, Andersson C, Ebbesen H, Jansen E, Klitgaard Kristensen D, Risebrobakken B, Salomonsen GR, Sarnthein M, Sejrup HP, Telford RJ (2007) Variations in temperature and extent of Atlantic Water in the northern North Atlantic during the Holocene, Quaternary Science Reviews 26: 3423-3440. DOI: https://doi.org/10.1016/j.quascirev.2007.10.005

Hansen B, Østerhus S (2000) North Atlantic - Nordic Seas exchanges. Progress in Oceanography 45: 109-208. DOI: https://doi.org/10.1016/S0079-6611(99)00052-X

Hass HC (2002) A method to reduce the influence of ice-rafted debris on a grain size record from northern Fram Strait, Arctic Ocean. Polar Research 21: 299-306. DOI: https://doi.org/10.1111/j.17518369.2002.tb00084.x

Hass HC, Kuhn G, Monien P, Brumsack H-J, Forwick M (2010) Climate fluctuations during the past two millennia as recorded in sediments from Maxwell Bay, South Shetland Islands, West Antarctica. Geological Society, London, Special Publications 344: 243-260. DOI: https://doi.org/10.1144/SP344.17

Hjort C (1997) Glaciation, climate history, changing marine levels and the evolution of the Northeast Water polynya. Journal of Marine Systems 10: 23-33. DOI: https://doi.org/10.1016/S09247963(96)00068-1

Jernas P, Kristensen DK, Husum K, Wilson L, Koç N (2013) Palaeoenvironmental changes of the last two millennia on the western and northern Svalbard shelf. Boreas 42: 236-255. DOI: https://doi.org/10.1111/j.1502-3885.2012.00293.x

Johannessen JA, Johannessen OM, Svendsen E, Shuchman R, Manley T, Campbell WJ, Josberger EG, Sandven S, Gascard JC, Olaussen T, Davidson K, Leer JV (1987) Mesoscale eddies in the Fram Strait marginal ice zone during the 1983 and 1984 Marginal Ice Zone Experiments. Journal of Geophysical Research: Oceans 92: 6754-6772. DOI: https://doi.org/10.1029/JC092iC07p06754

Johannessen OM (1986) Brief Overview of the Physical Oceanography. In: Hurdle BG (ed) The Nordic Seas. New York: Springer, pp. 103-128. DOI: https://doi.org/10.1007/978-1-4615-8035-5_4

Karcher MJ, Gerdes R, Kauker F, Köberle C (2003) Arctic warming: Evolution and spreading of the 1990s warm event in the Nordic seas and the Arctic Ocean. Journal of Geophysical Research: Oceans 108: 1-16. DOI: https://doi.org/10.1029/2001JC001265

Kawasaki T, Hasumi H (2016) The inflow of Atlantic water at the Fram Strait and its interannual variability. Journal of Geophysical Research: Oceans 121: 502-519. DOI: https://doi.org/10.1002/2015JC011375

Koenig Z, Provost C, Sennéchael N, Garric G, Gascard J-C (2017) The Yermak Pass Branch: A Major Pathway for the Atlantic Water North of Svalbard?. Journal of Geophysical Research: Oceans 122: 9332-9349. DOI: https://doi.org/10.1002/2017JC013271 
Kuhlbrodt T, Griesel A, Montoya M, Levermann A, Hofmann M, Rahmstorf S (2007) On the driving processes of the Atlantic meridional overturning circulation. Reviews of Geophysics 45: 1-32. DOI: https://doi.org/10.1029/2004RG000166

Larsen NK, Levy LB, Carlson AE, Buizert C, Olsen J, Strunk A, Bjørk AA, Skov DS (2018) Instability of the Northeast Greenland Ice Stream over the last 45,000 years. Nature Communications 9: 1872. DOI: https://doi.org/10.1038/s41467-018-04312-7

Laskar J, Robutel P, Joutel F, Gastineau M, Correia ACM, Levrard B (2004) A long-term numerical solution for the insolation quantities of the Earth. Astronomy \& Astrophysics 428: 261-285. DOI: https://doi.org/10.1051/0004-6361:20041335

Laukert G, Frank M, Bauch D, Hathorne EC, Rabe B, Von Appen W-J, Wegner C, Zieringer M, Kassens $H$ (2017) Ocean circulation and freshwater pathways in the Arctic Mediterranean based on a combined $\mathrm{Nd}$ isotope, REE and oxygen isotope section across Fram Strait. Geochimica et Cosmochimica Acta 202: 285-309. DOI: https://doi.org/10.1016/j.gca.2016.12.028

Lubinski DJ, Polyak L, Forman SL (2001) Freshwater and Atlantic water inflows to the deep northern Barents and Kara seas since ca. $1314 \mathrm{C}$ ka: foraminifera and stable isotopes. Quaternary Science Reviews 20: 1851-1879. DOI: https://doi.org/10.1016/S0277-3791(01)00016-6

Manley TO (1995) Branching of Atlantic Water within the Greenland-Spitsbergen Passage: An estimate of recirculation. Journal of Geophysical Research: Oceans 100: 20627-20634. DOI: https://doi.org/10.1029/95JC01251

Marnela M, Rudels B, Houssais M-N, Beszczynska-Möller A, Eriksson PB (2013) Recirculation in the Fram Strait and transports of water in and north of the Fram Strait derived from CTD data. Ocean Science 9: 499-519. DOI: https://doi.org/10.5194/os-9-499-2013

Marshall J, Schott F (1999) Open-ocean convection: Observations, theory, and models. Reviews of Geophysics 37: 1-64. DOI: https://doi.org/10.1029/98RG02739

Matul A, Spielhagen RF, Kazarina G, Kruglikova S, Dmitrenko O, Mohan R (2018) Warm-water events in the Fram Strait during the last 2000 years as revealed by different microfossil groups. Polar Research 37: 1540243. DOI: https://doi.org/10.1080/17518369.2018.1540243.

Mayer C, Schaffer J, Hattermann T, Floricioiu D, Krieger L, Dodd PA, Kanzow T, Licciulli C, Schannwell C (2018) Large ice loss variability at Nioghalvfjerdsfjorden Glacier, Northeast-Greenland. Nature Communications 9: 1-11. DOI: https://doi.org/10.1038/s41467-018-05180-x

McCave IN, Manighetti B, Robinson SG (1995) Sortable silt and fine sediment size/composition slicing: Parameters for palaeocurrent speed and palaeoceanography. Paleoceanography 10: 593-610. DOI: https://doi.org/10.1029/94PA03039

Mouginot J, Rignot E, Scheuchl B, Fenty I, Khazendar A, Morlighem M, Buzzi A, Paden J (2015) Fast retreat of Zachariæ Isstrøm, northeast Greenland. Science 350: 1357-1361. DOI: https://doi.org/10.1126/science.aac7111

Müller J, Werner K, Stein R, Fahl K, Moros M, Jansen E (2012) Holocene cooling culminates in sea ice oscillations in Fram Strait. Quaternary Science Reviews 47: 1-14. DOI: https://doi.org/10.1016/j.quascirev.2012.04.024

Nørgaard-Pedersen N, Spielhagen RF, Erlenkeuser H, Grootes PM, Heinemeier J, Knies J (2003) Arctic Ocean during the Last Glacial Maximum: Atlantic and polar domains of surface water mass 
distribution and ice cover. Paleoceanography 18: 1063. DOI: https://doi.org/10.1029/2002PA000781 Nürnberg D, Wollenburg I, Dethleff D, Eicken H, Kassens H, Letzig T, Reimnitz E, Thiede J (1994) Sediments in Arctic sea ice: Implications for entrainment, transport and release. Marine Geology, 4th International Conference on Paleoceanography (ICP IV) 119: 185-214. DOI: https://doi.org/10.1016/0025-3227(94)90181-3

Olsen A, Ninnemann U (2010) Large $\delta 13 \mathrm{C}$ Gradients in the Preindustrial North Atlantic Revealed. Science 330: 658-659. DOI: https://doi.org/10.1126/science.1193769

Otterå OH, Drange H, Bentsen M, Kvamstø NG, Jiang D (2003) The sensitivity of the present-day Atlantic meridional overturning circulation to freshwater forcing. Geophysical Research Letters 17: 1898. DOI: https://doi.org/10.1029/2003GL017578

Pados T, Spielhagen RF, Bauch D, Meyer H, Segl M (2015) Oxygen and carbon isotope composition of modern planktic foraminifera and near-surface waters in the Fram Strait (Arctic Ocean) - a casestudy. Biogeosciences 12: 1733-1752. DOI: https://doi.org/10.5194/bg-12-1733-2015

Pados T, Spielhagen RF (2014) Species distribution and depth habitat of recent planktic foraminifera in Fram Strait, Arctic Ocean. Polar Research 33: 1-12. DOI: https://doi.org/10.3402/polar.v33.22483 Parnell AC, Haslett J, Allen JRM, Buck CE, Huntley B (2008) A flexible approach to assessing synchroneity of past events using Bayesian reconstructions of sedimentation history. Quaternary Science Reviews 27: 1872-1885. DOI: https://doi.org/10.1016/j.quascirev.2008.07.009 Pfuhl HA, Shackleton NJ (2004) Two proximal, high-resolution records of foraminiferal fragmentation and their implications for changes in dissolution. Deep Sea Research Part I: Oceanographic Research Papers 51: 809-832. DOI: https://doi.org/10.1016/j.dsr.2004.02.003

Phillips RL, Grantz A (2001) Regional variations in provenance and abundance of ice-rafted clasts in Arctic Ocean sediments: implications for the configuration of late Quaternary oceanic and atmospheric circulation in the Arctic. Marine Geology 172: 91-115. DOI: https://doi.org/10.1016/S00253227(00)00101-8

Polyakov IV, Pnyushkov AV, Alkire MB, Ashik IM, Baumann TM, Carmack EC, Goszczko I, Guthrie J, Ivanov VV, Kanzow T, Krishfield R, Kwok R, Sundfjord A, Morison J, Rember R, Yulin A (2017) Greater role for Atlantic inflows on sea-ice loss in the Eurasian Basin of the Arctic Ocean. Science 356: 285-291. DOI: https://doi.org/10.1126/science.aai8204

Poole DAR, Dokken TM, Hald M, Polyak L (1994) Stable isotope fractionation in recent benthic foraminifera from the Barents and Kara Seas. PhD Thesis, University of Tromsø, Norway.

Quadfasel D, Gascard J-C, Koltermann K-P (1987) Large-scale oceanography in Fram Strait during the 1984 Marginal Ice Zone Experiment. Journal of Geophysical Research: Oceans 92: 6719-6728. DOI: https://doi.org/10.1029/JC092iC07p06719

Rahmstorf S (2002) Ocean circulation and climate during the past 120,000 years. Nature 419: 207214. DOI: https://doi.org/10.1038/nature01090

Reimer PJ, Bard E, Bayliss A, Beck JW, Blackwell PG, Ramsey CB, Buck CE, Cheng H, Edwards RL, Friedrich M, Grootes PM, Guilderson TP, Haflidason H, Hajdas I, Hatté C, Heaton TJ, Hoffmann DL, Hogg AG, Hughen KA, Kaiser KF, Kromer B, Manning SW, Niu M, Reimer RW, Richards DA, Scott EM, Southon JR, Staff RA, Turney CSM, Van der Plicht J (2013) IntCal13 and Marine13 Radiocarbon Age Calibration Curves 0-50,000 Years cal BP. Radiocarbon 55: 1869-1887. DOI: 
https://doi.org/10.2458/azu_js_rc.55.16947

Richter ME, Von Appen W-J, Wekerle C (2018) Does the East Greenland Current exist in the Northern Fram Strait?. Ocean Science 14: 1147-1165. DOI: https://doi.org/10.5194/os-14-1147-2018

Richter TO, Van Der Gaast S, Koster B, Vaars A, Gieles R, De Stigter HC, De Haas H, Van Weering TCE (2006) The Avaatech XRF Core Scanner: technical description and applications to NE Atlantic sediments. Geological Society, London, Special Publications 267: 39-50. DOI: https://doi.org/10.1144/GSL.SP.2006.267.01.03

Risebrobakken B, Dokken T, Smedsrud LH, Andersson C, Jansen E, Moros M, Ivanova EV (2011) Early Holocene temperature variability in the Nordic Seas: The role of oceanic heat advection versus changes in orbital forcing. Paleoceanography 26: 1-17. DOI: https://doi.org/10.1029/2011PA002117 Rothwell RG, Croudace IW (2015) Twenty Years of XRF Core Scanning Marine Sediments: What Do Geochemical Proxies Tell Us?. In: Croudace IW, Rothwell RG (eds) Micro-XRF Studies of Sediment Cores: Applications of a non-destructive tool for the environmental sciences. Dordrecht: Springer, pp. 25-101. DOI: https://doi.org/10.1007/978-94-017-9849-5

Rudels B, Björk G, Nilsson J, Winsor P, Lake I, Nohr C (2005) The interaction between waters from the Arctic Ocean and the Nordic Seas north of Fram Strait and along the East Greenland Current: results from the Arctic Ocean-02 Oden expedition. Journal of Marine Systems 55: 1-30. DOI: https://doi.org/10.1016/j.jmarsys.2004.06.008

Rudels B, Quadfasel D (1991) Convection and deep water formation in the Arctic Ocean-Greenland Sea System. Journal of Marine Systems 2: 435-450. DOI: https://doi.org/10.1016/09247963(91)90045-V

Sarnthein M, Kreveld SV, Erlenkeuser H, Grootes PM, Kucera M, Pflaumann U, Schulz M (2003) Centennial-to-millennial-scale periodicities of Holocene climate and sediment injections off the western Barents shelf, $75^{\circ} \mathrm{N}$. Boreas 32: 447-461. DOI: https://doi.org/10.1111/j.1502-3885.2003.tb01227.x

Schauer U, Fahrbach E, Osterhus S, Rohardt G (2004) Arctic warming through the Fram Strait: Oceanic heat transport from 3 years of measurements. Journal of Geophysical Research: Oceans 109: 1-14. DOI: https://doi.org/10.1029/2003JC001823

Schlichtholz P, Houssais M-N (1999) An inverse modeling study in Fram Strait. Part I: dynamics and circulation. Deep Sea Research Part II: Topical Studies in Oceanography 46: 1083-1135. DOI: https://doi.org/10.1016/S0967-0645(99)00018-1

Spielhagen RF, Werner K, Sørensen SA, Zamelczyk K, Kandiano E, Budeus G, Husum K, Marchitto TM, Hald M (2011) Enhanced Modern Heat Transfer to the Arctic by Warm Atlantic Water. Science 331: 450-453. DOI: https://doi.org/10.1126/science.1197397

Spielhagen RF, Erlenkeuser H (1994) Stable oxygen and carbon isotopes in planktic foraminifers from Arctic Ocean surface sediments: Reflection of the low salinity surface water layer. Marine Geology, 4th International Conference on Paleoceanography (ICP IV) 119: 227-250. DOI: https://doi.org/10.1016/0025-3227(94)90183-X

Spofforth DJA, Pälike H, Green D (2008) Paleogene record of elemental concentrations in sediments from the Arctic Ocean obtained by XRF analyses. Paleoceanography 23: PA1S09. DOI: https://doi.org/10.1029/2007PA001489

Stein R (2016) The Expedition PS93.1 of the Research Vessel POLARSTERN to the Greenland Sea 
and the Fram Strait in 2015. Alfred Wegener Institute for Polar and Marine Research 695. Reports on Polar and Marine Research: 151. DOI: https://doi.org/10.2312/BzPM_0695_2016

St John K, Passchier S, Tantillo B, Darby D, Kearns L (2015) Microfeatures of modern sea-ice-rafted sediment and implications for paleo-sea-ice reconstructions. Annals of Glaciology 56: 83-93. DOI: https://doi.org/10.3189/2015AoG69A586

Strunk A, Larsen NK, Nilsson A, Seidenkrantz M-S, Levy LB, Olsen J, Lauridsen TL (2018) Relative Sea-Level Changes and Ice Sheet History in Finderup Land, North Greenland. Frontiers in Earth Science 6: 129. DOI: https://doi.org/10.3389/feart.2018.00129

Stuiver M, Reimer PJ (1993) Extended 14C Data Base and Revised CALIB 3.0 14C Age Calibration Program. Radiocarbon 35: 215-230. DOI: https://doi.org/10.1017/S0033822200013904

Swift JH (1986) The Arctic Waters. In: Hurdle BG (ed) The Nordic Seas. New York: Springer, pp. 129154. DOI: https://doi.org/10.1007/978-1-4615-8035-5_5

Syring N, Stein R, Fahl K, Vahlenkamp M, Zehnich M, Spielhagen RF, Niessen F (2020) Holocene changes in sea-ice cover and polynya formation along the eastern North Greenland shelf: New insights from biomarker records. Quaternary Science Reviews 231: 106173. DOI: https://doi.org/10.1016/j.quascirev.2020.106173

Telesiński MM, Spielhagen RF, Bauch HA (2014) Water mass evolution of the Greenland Sea since late glacial times. Climate of the Past 10: 123-136. DOI: https://doi.org/10.5194/cp-10-123-2014 Vare LL, Massé G, Gregory TR, Smart CW, Belt ST (2009) Sea ice variations in the central Canadian Arctic Archipelago during the Holocene. Quaternary Science Reviews 28: 1354-1366. DOI: https://doi.org/10.1016/j.quascirev.2009.01.013

Vinje T, Finnekåsa $\varnothing$ (1986) The ice transport through the Fram Strait. Norsk Polarinstitutt Skrifter 186: 1-39.

Volkmann R (2000) Planktic foraminifer ecology and stable isotope geochemistry in the Arctic Ocean: implications from water column and sediment surface studies for quantitative reconstructions of oceanic parameters. Alfred Wegener Institute for Polar and Marine Research 361. Reports on Polar and Marine Research: 100. DOI: https://doi.org/10.2312/BzP_0361_2000.

Volkmann R, Mensch M (2001) Stable isotope composition ( $\delta 180, \delta 13 \mathrm{C}$ ) of living planktic foraminifers in the outer Laptev Sea and the Fram Strait. Marine Micropaleontology 42: 163-188. DOI: https://doi.org/10.1016/S0377-8398(01)00018-4

Walker M, Head MH, Berklehammer M, Bjørck S, Cheng H, Cwynar L, Fisher D, Gkinis V, Long A, Lowe J, Newnham R, Rasmussen SO, Weiss H (2018) Formal ratification of the subdivision of the Holocene Series/Epoch (Quaternary System/Period): two new Global Boundary Stratotype Sections and Points (GSSPS) and three new stages/subseries. Episodes 41 (4): 213-223. DOI: https://doi.org/10.18814/epiiugs/2018/018016

Werner K, Müller J, Husum K, Spielhagen RF, Kandiano E, Polyak L (2016) Holocene sea subsurface and surface water masses in the Fram Strait-Comparisons of temperature and sea-ice reconstructions. Quaternary Science Reviews, Special Issue: PAST Gateways (Palaeo-Arctic Spatial and Temporal Gateways) 147: 194-209. DOI: https://doi.org/10.1016/j.quascirev.2015.09.007

Werner K, Spielhagen RF, Bauch D, Hass HC, Kandiano E (2013) Atlantic Water advection versus sea-ice advances in the eastern Fram Strait during the last 9 ka: Multiproxy evidence for a two-phase 
Holocene. Paleoceanography 28: 283-295. DOI: https://doi.org/10.1002/palo.20028

Werner K, Spielhagen RF, Bauch D, Hass HC, Kandiano E, Zamelczyk K (2011) Atlantic Water advection to the eastern Fram Strait - Multiproxy evidence for late Holocene variability. Palaeogeography, Palaeoclimatology, Palaeoecology 308: 264-276. DOI: https://doi.org/10.1016/j.palaeo.2011.05.030

Zamelczyk K, Rasmussen TL, Husum K, Haflidason H, De Vernal A, Krogh Ravna E, Hald M, HillaireMarcel C (2012) Paleoceanographic changes and calcium carbonate dissolution in the central Fram Strait during the last 20 ka. Quaternary Research 78: 405-416. DOI: https://doi.org/10.1016/j.yqres.2012.07.006 


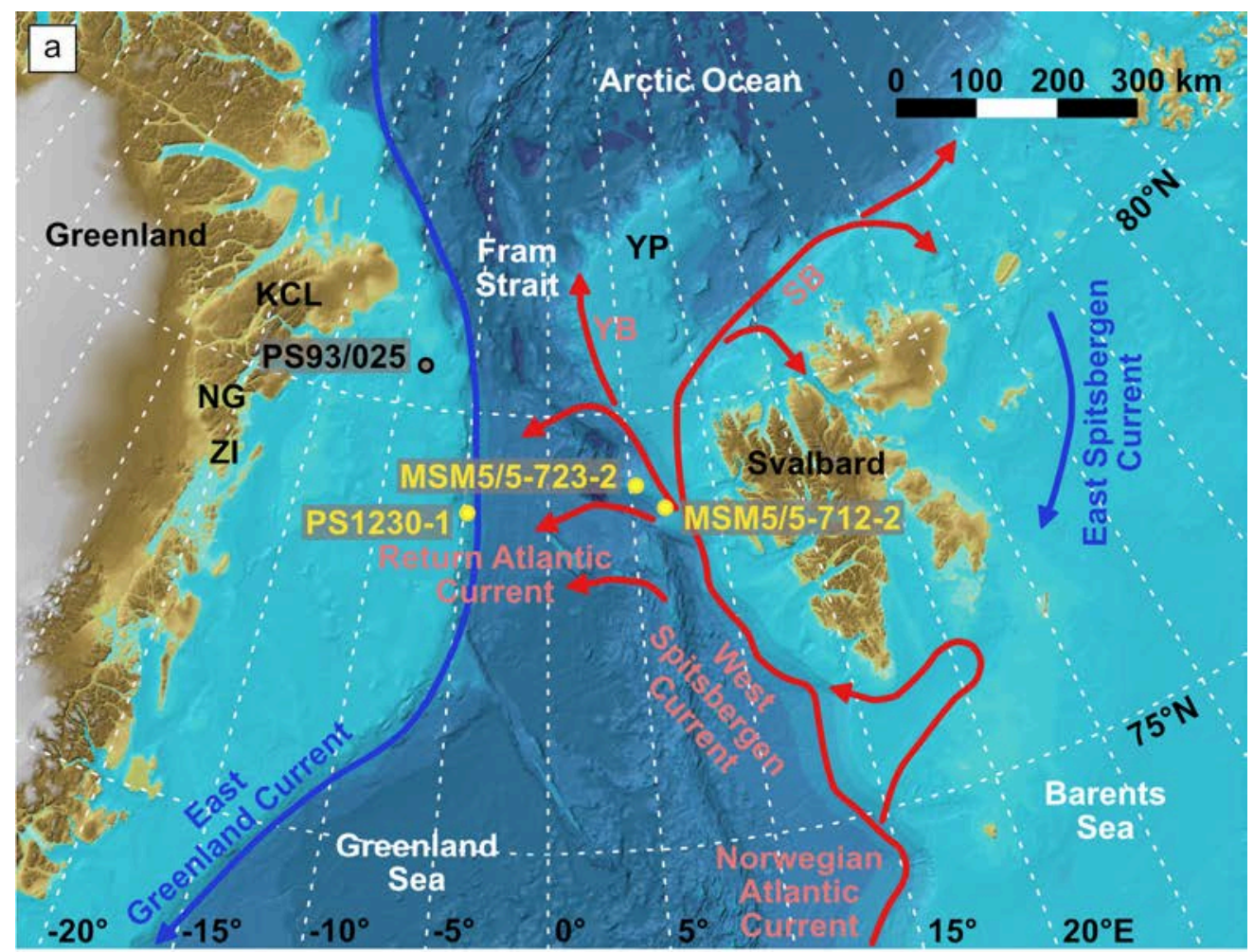

Bathymetric and topographic tints $(\mathrm{m})$

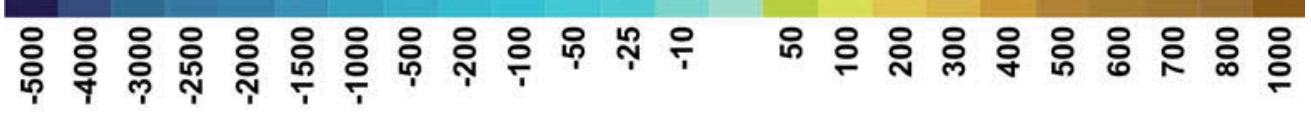

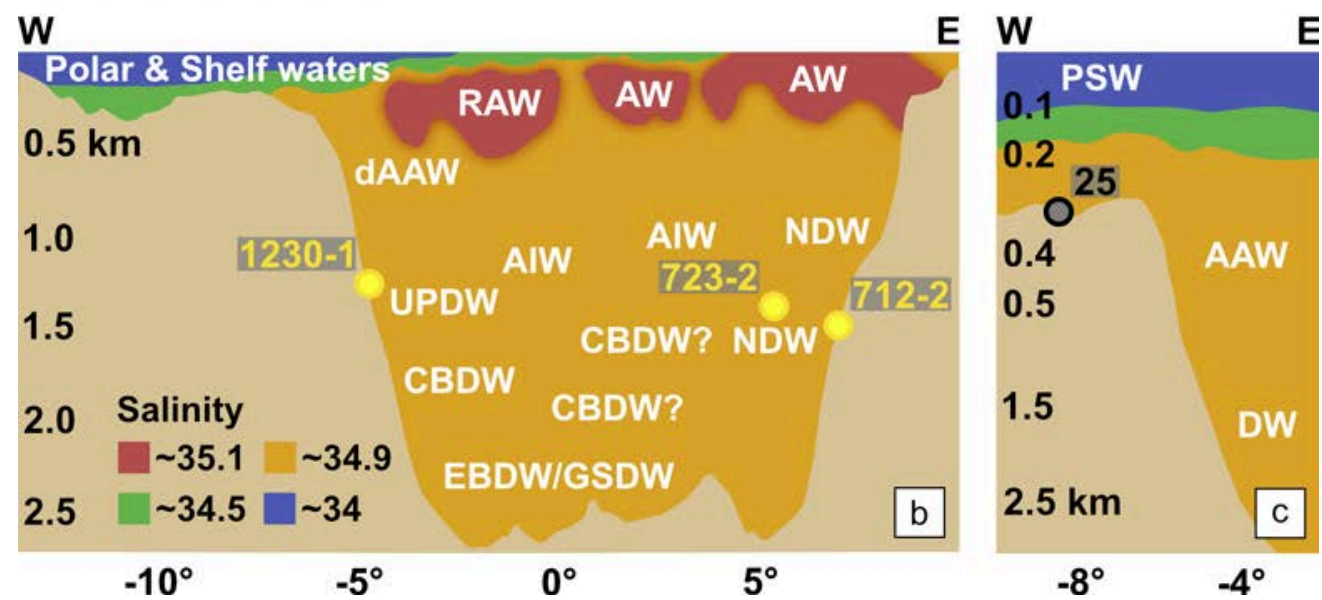

Figure 1 

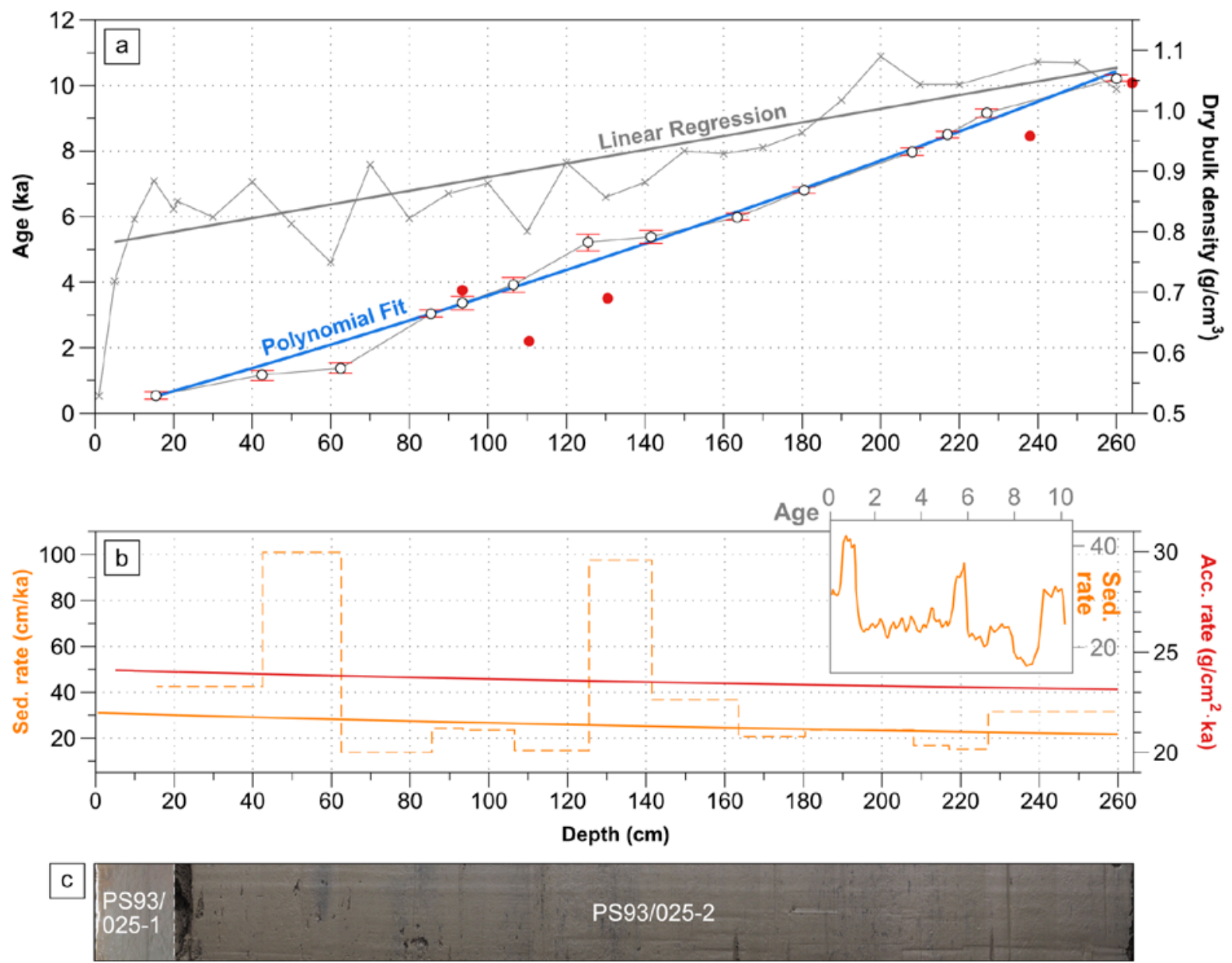

Figure 2 


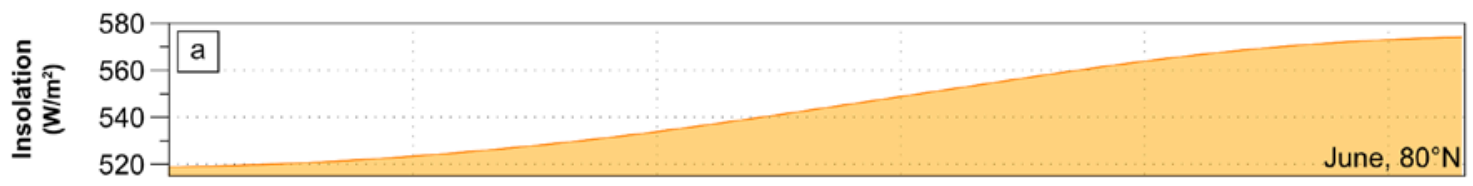

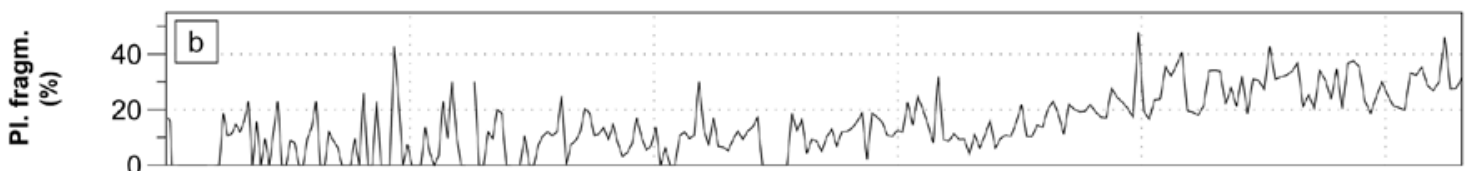
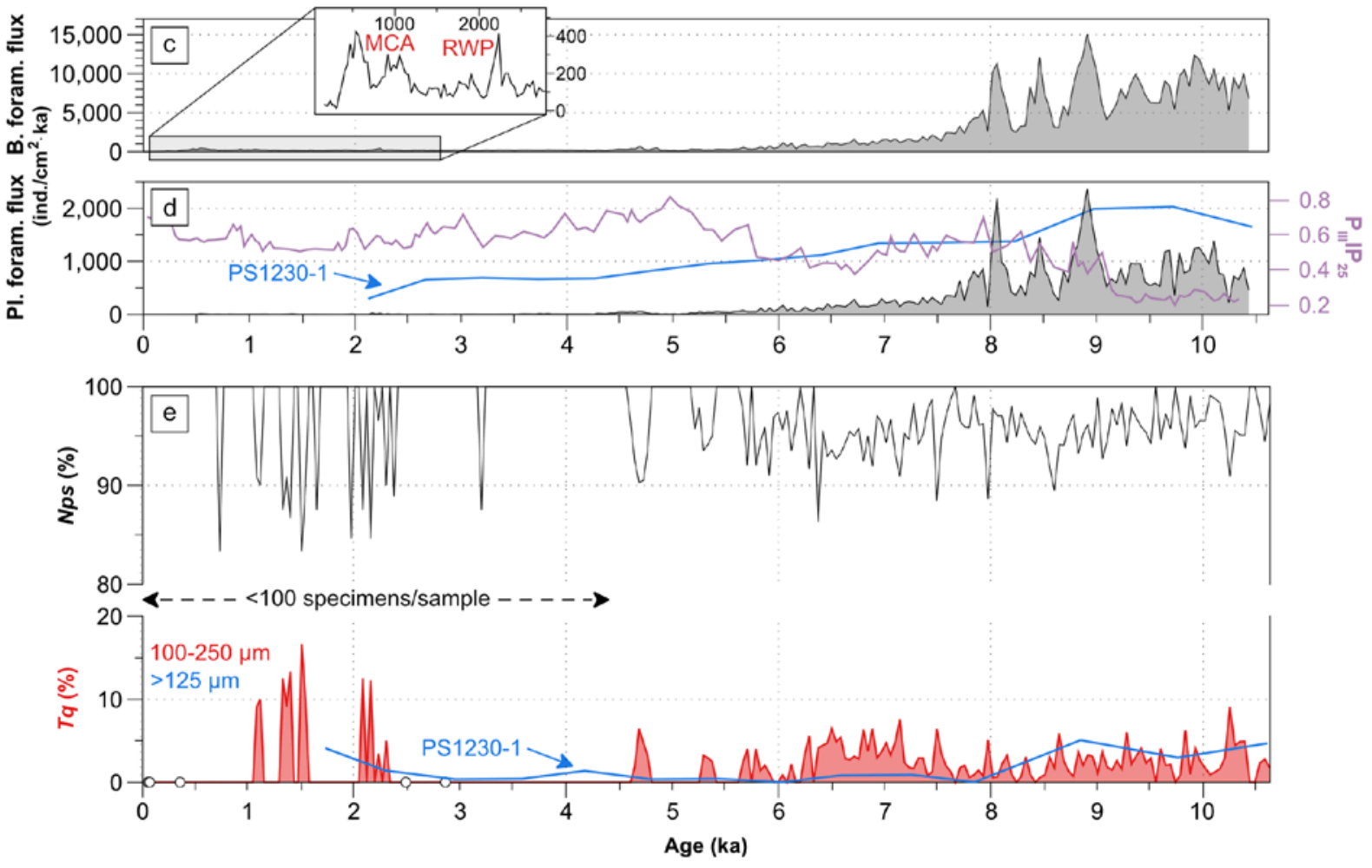

Figure 3 

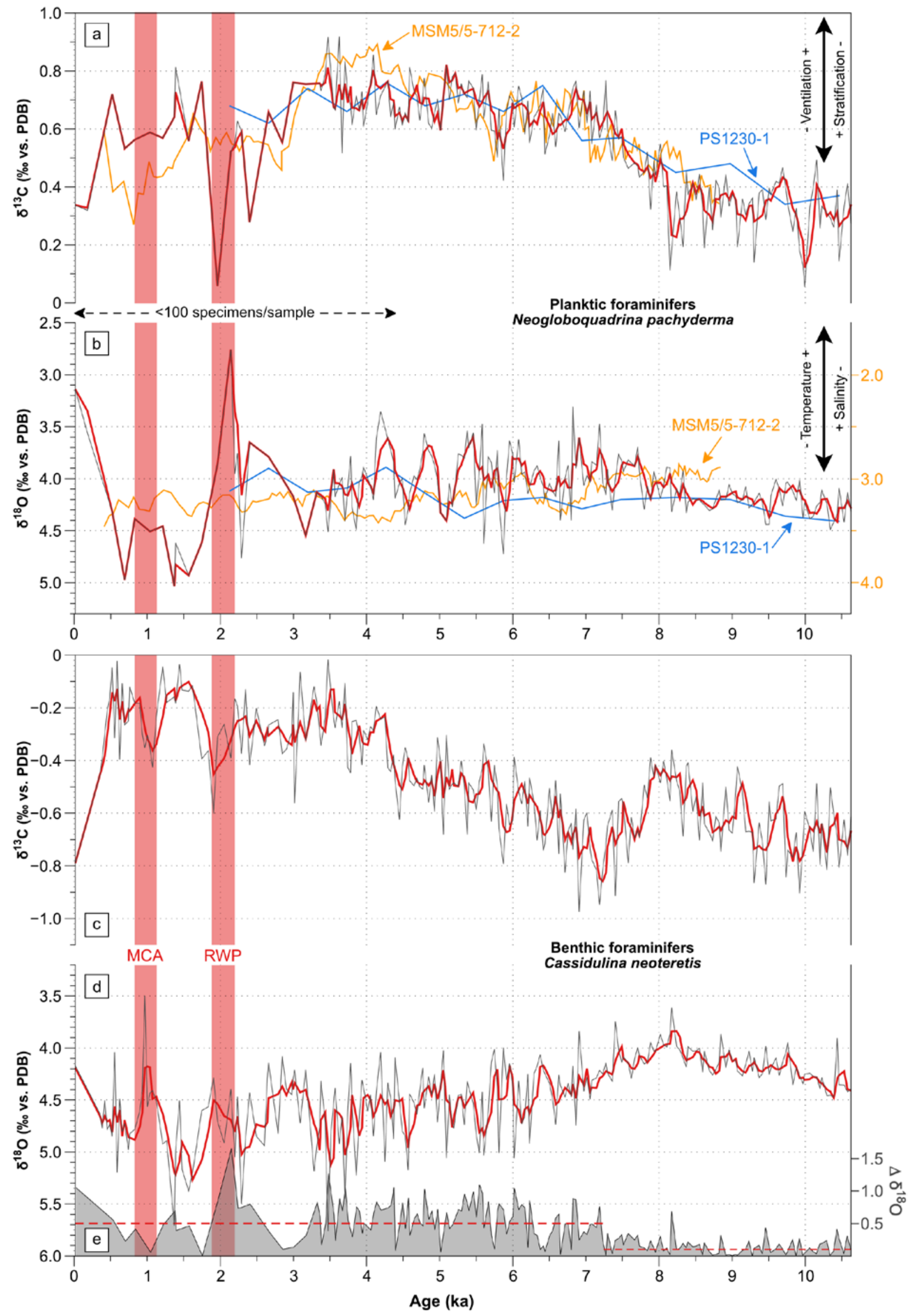

Figure 4 


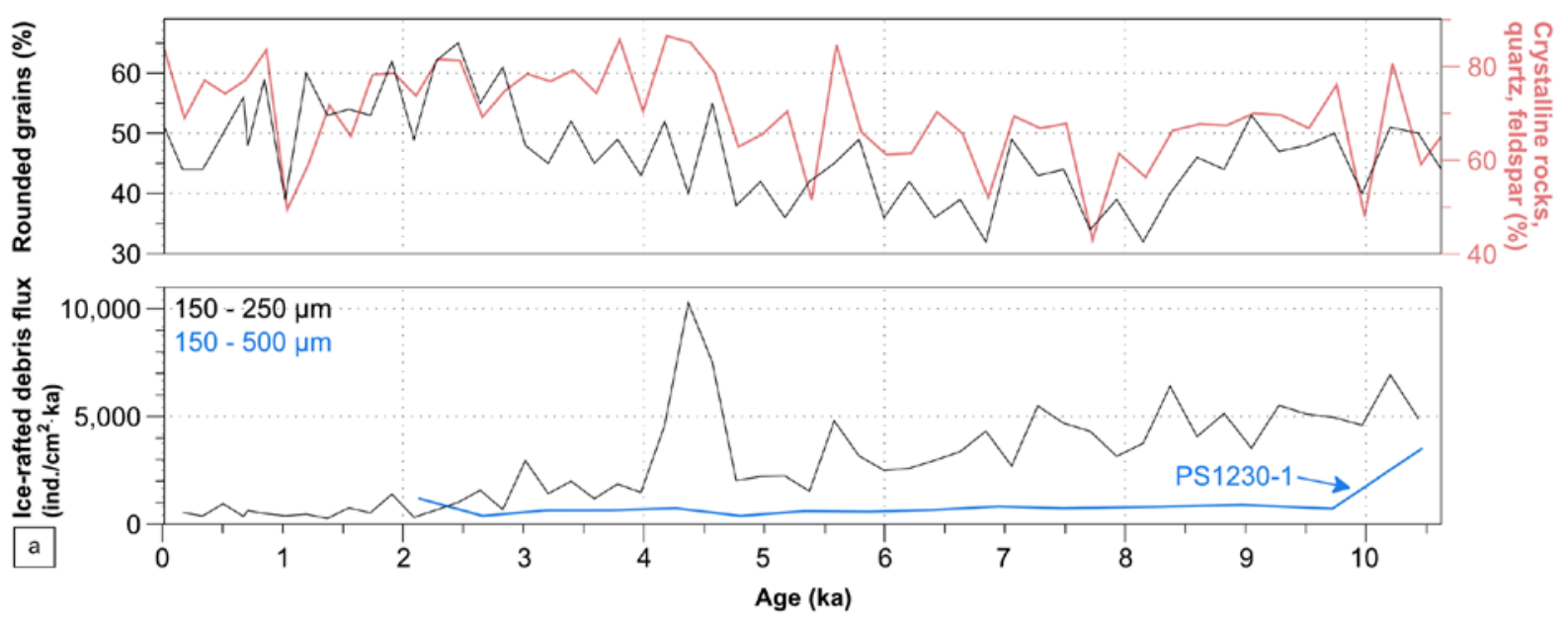

b $\square$ Clastic sedimentary rocks (e.g., siltstones) $(<4.0 \%)$

Metamorphic rocks (e.g., quartzites), volcanic rocks (e.g., basalt), olivine grains, volcanic glass shards, mica Crystalline rocks, quartz and feldspar

Limestones and dolomites $(<0.5 \%)$
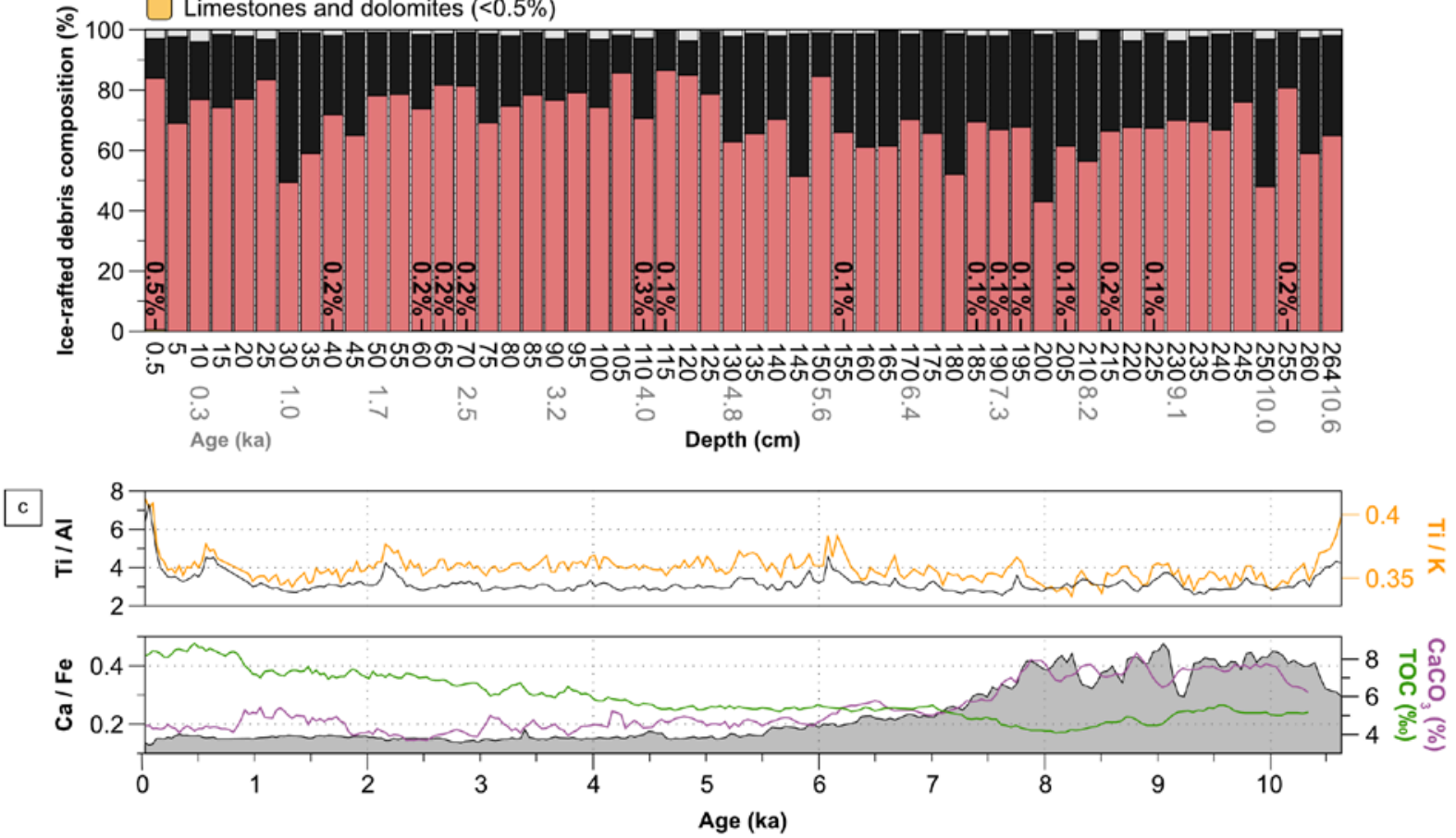

Figure 5 

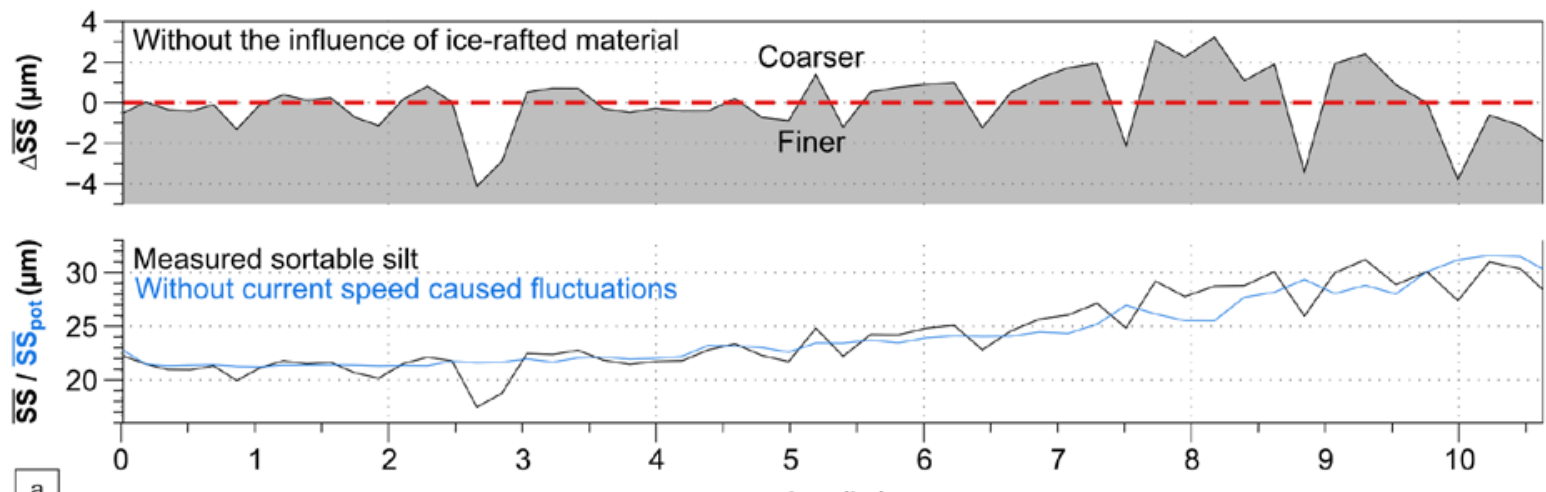

a

Age (ka)

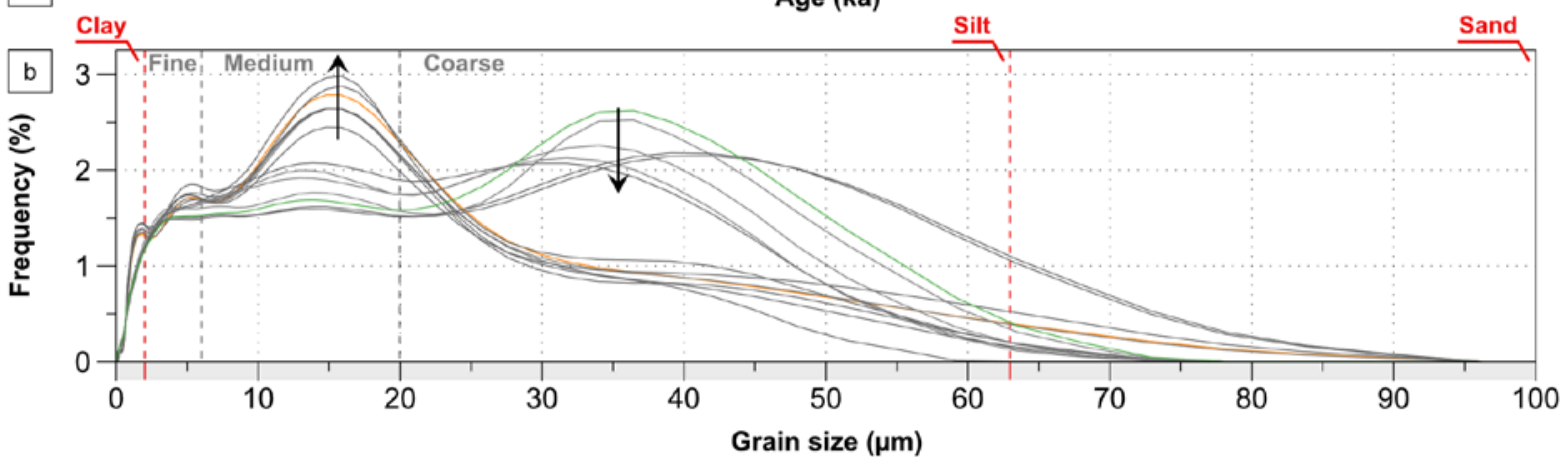

c
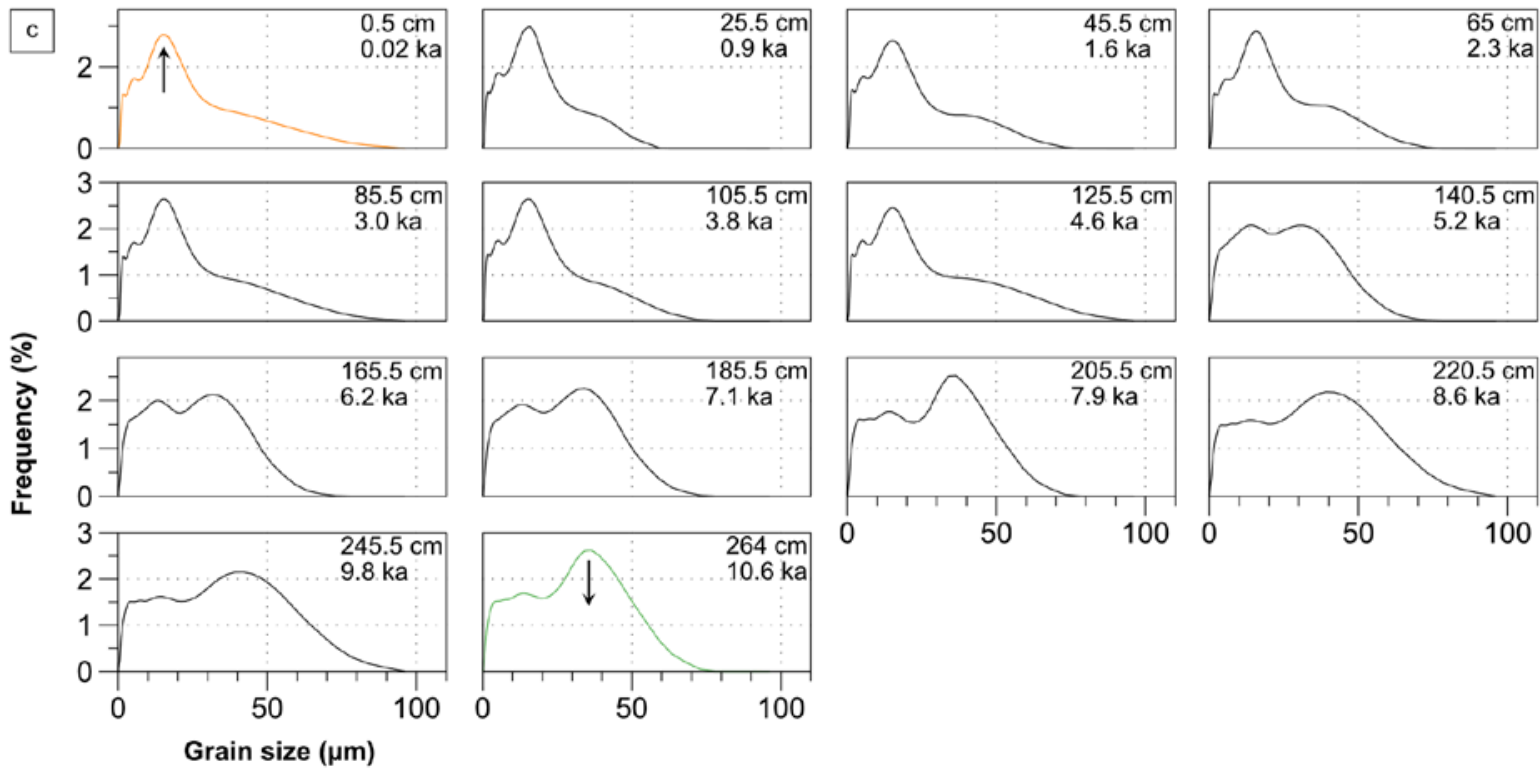

0

50

100

Figure 6 